Portland State University

PDXScholar

1975

\title{
Towards the integration of the historical and structural theories of urban form
}

David Tilford Martin

Portland State University

Follow this and additional works at: https://pdxscholar.library.pdx.edu/open_access_etds

Part of the Social Policy Commons, Urban Studies Commons, and the Urban Studies and Planning Commons

Let us know how access to this document benefits you.

\section{Recommended Citation}

Martin, David Tilford, "Towards the integration of the historical and structural theories of urban form" (1975). Dissertations and Theses. Paper 2411.

https://doi.org/10.15760/etd.2408

This Thesis is brought to you for free and open access. It has been accepted for inclusion in Dissertations and Theses by an authorized administrator of PDXScholar. Please contact us if we can make this document more accessible: pdxscholar@pdx.edu. 
AN ABSTRACT OF THE THESIS OF David Tilford Martin for the Master of Science in Sociology presented August 18, 1975.

Title: Towards the Integration of the Historical and Structural Theories of Urban Form.

APPROVED BY MEMBERS OF THE THESIS COMMITTEE:

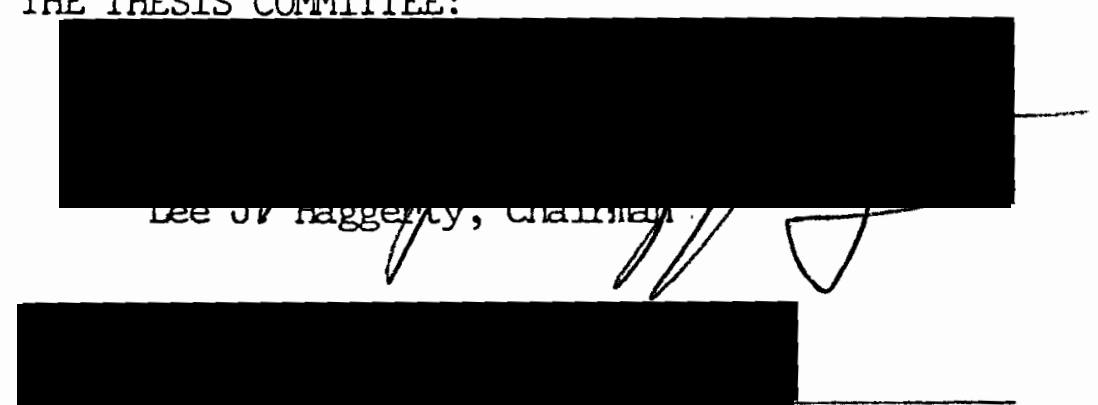

Jamgs E. Weiss

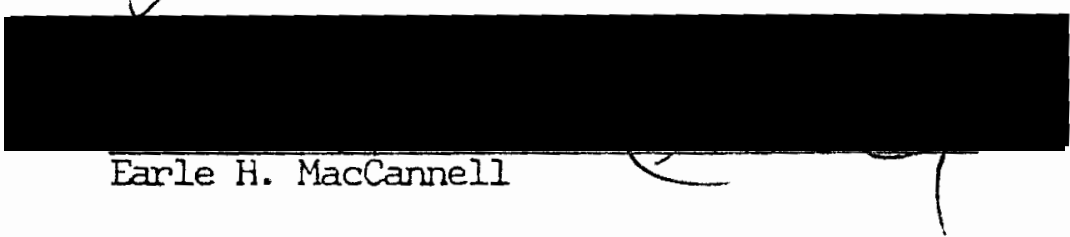

In this thesis we examine the effect which the obsolescence of central city housing exerts on the decentralization within urban areas of high status residents. In particulas, we investigate whether housing obsolescence is a usefur addition to a model which explains the decentralization of high status residents in terms of the intensity of competition for central city land.

All of our data are official Census figures for 1970. The subjects of our study are Standard Metropolitan Statistical Areas (SMSA's) whose central city had a population of 100,000 or more. From this group we delete the New York and Chicago Consolidated Areas because 
of their great size and the minkn of municipalities included within their borders. For each SISA we compute the percentage of its families and unrelated individuals who had an income of greater than $\$ 25,000$ and who lived in the central city. We then statistically control for variation across SMSA's in the decentralization of population and employment. The decentralization of population is measured by the percentage of the SMSA population which resided within the central city. The decentralization of employment is measured by the percentage of SISA jobs which were located within the central city.

Once we have controlled the decentralization of the well-to-do for the decentralization of population and the decentralization of employment, we regress it on population density, housing obsolescence, and city age. Population density is persons per square mile in the central city. Housing obsolescence is the percentage of the central city housing structures which were twenty years old or older. City age is the number of decades since the central city attained a population of 50,000 .

In our study we demonstrate that population density exerts a considerably stronger effect on the decentralization of the well-to-do than is exerted by housing obsolescence. We also demonstrate that most of city age's effect on the decentralization of the well-to-do can be explained by city age's effect on population density and housing obsolescence. 
TOWARDS THE INTEGRATION OF THE

HISTORICAL AND STRUCIURAL THEORIES OF URBAN FORM

by

DAVID TILFORD MARTIN

A thesis submitted in partial fulfillment of the requirements for the degree of

\author{
MASTER OF SCIENCE \\ in \\ SOCIOLOGY
}

Portland State University

1975 
TO THE OFFICE OF GRADUATE STUDIES AND RESEARCH:

The members of the Committee approve the thesis of David

Tilford Martin presented August 18, 1975.

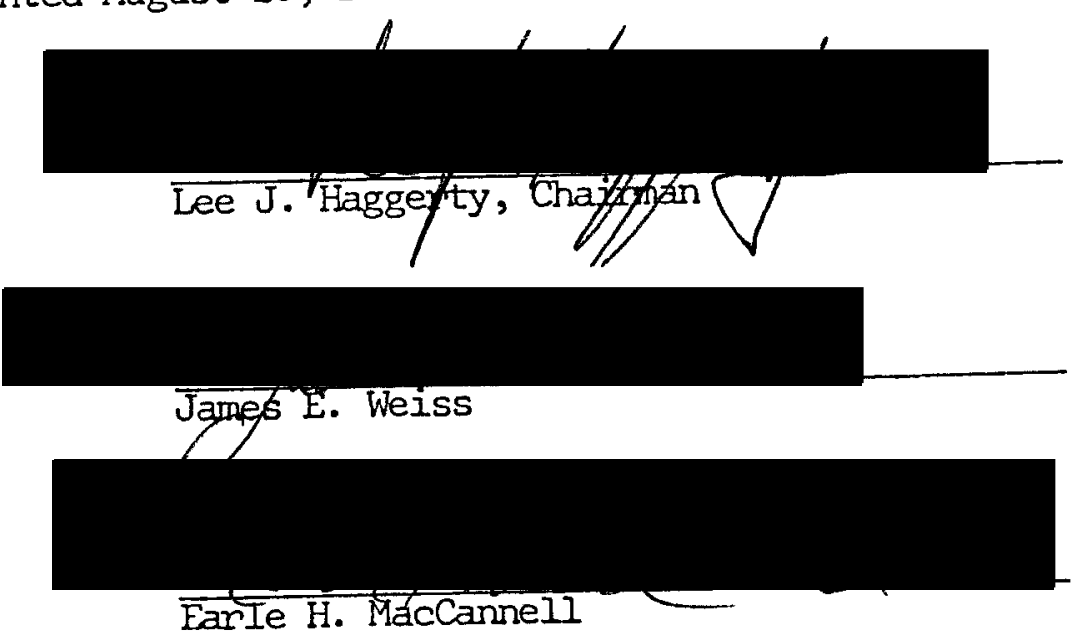

APPROVED:

Robert W. Shotola, Head, Department of Sociology

DavidT. Clark, Dean of Gracuate Studies and Research

August 18, 1975 


\section{ACKNOWLEDGMENTS}

My passage through the graduate program in sociology at Portland State University has been almost without exception a pleasant one. However, there are several people who have made the experience particularly memorable and I wish to thank them here. My fellow graduate student Peter Munroe was interested enough in the subject of my thesis, and knowledgeable enough in the area, to be able to make two suggestions which eased my work considerably. In addition, I wish to express my gratitude for the friendliness and encouragement shown me by Dr. Lee Haggerty, Dr. John James, Dr. Barry Lebowitz, Dr. Wilson Record, Dr. Robert Shotola, and Dr. James Weiss. 


\section{CHAPTER}

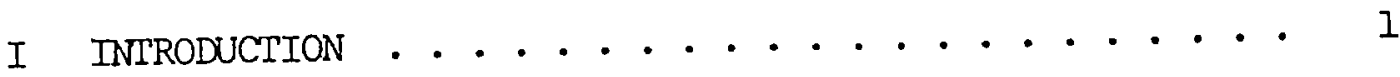

II TRENDS IN SUBURBANIZATION AND THEIR IMPORTANCE .... 5

Overview of Trends in Suburbanization ...... 5

General Trends

The Suburbanization of Business and Industry Concentration of Minorities in the Central Cities

The Proliferation of Metropolitan Goverments . . .

Defensive Incorporation

Unequal Division of Resources

The Increasing Fiscal Strain in the Large Central Cities

Costs Arising from the Concentration of the Poor and Minorities

Suburban Exclusion of the Poor Influence of the Federal Government on Economic Integration

Effect of the Trickle-Down Housing Policy Suburban Exploitation of the Central City Tax Strain in the Central Cities 
The Declining Quality of Central City Public

The Increasing Cost of Central City Schools

Potential Solutions

Solutions for the Hiatus Between Resources and Needs

Metropolitan Consolidation

Opening the Suburbs

Sumary . . . . . . . . . . . . . . . . . .

III THEORETICAL ISSUES INVOLVED IN INTEGRATING THE HISTORICAL AND STRUCTURAL THEORIES OF URBAN FORM . . . • • 35

IV METHOLOGY

Units of Study ........... 51

Variables ......... 52

Models Used in the Analysis . . . . . . . 56

Model 1

Model 2

Model 3

$\checkmark$ ANALYSTS OF DATA .................... 60

VI CONCUUSTONS $\cdot \cdots \cdot \ldots 7$

BIBLIOGRAPHY $0 . . . . . . \cdots 74$ 


\section{LIST OF TABLES}

TABLE

PAGE

I Zero-Order Correlations Among the Variables in Figure $3 . .6 \dot{6}$ 
1 Path Diagram of Model 1........... 60

2 Path Diagram of Model 2.................... 61

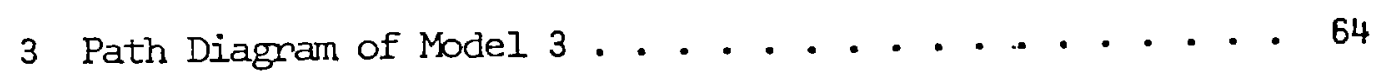

4 Expanded Historical/Structural Model . . . . . 73 


\section{CHAPTER I}

\section{INTRODUCTION}

In this study we will attempt to further the integration of the historical and structural theories of urban form. In particular, we will investigate the hypothesis found in the work of both Leo Schnore and Avery Guest that a central city's population growth during earlier enas affects the decentralization of high status residents within the city independently of the population growth's effect on the intensity of competition for central city land because of the effect which the population growth exerts on the location of obsolescent housing within the urban area. We will test this hypothesis by regressing a measure of the decentralization of high status residents within Standard Metropolitan Statistical Areas (SMSA's) on measures of the density of . population within the central city and the decentralization of obsolescent housing. In addition, we will investigate questions raised by Schnore and Guest concerning the importance of city age (measured by the number of decades since the city attained a population of 50,000 ) in the explanation of the decentralization of high status residents.

our data will be official Census figures. By using these figures we are avoiding actually defining what we mean by a "city." Louis Wirth has suggested a sociological definition of the city as "a relatively large, dense, and permanent settlement of socially heterogeneous 
individuals." 1 This definition lacks precision since it does not specify how lange, how dense, etc. And yet it is sufficient for our purposes.

However cities are defined, their importance to society goes far beyond the number of their residents: much of the great volume of production and exchange of goods and services upon which a modern society depends occurs in cities, while those sectors of the econony which are less highly urbanized such as mining and agriculture turn out in fact not to be independent of cities but to be controlled financially and adristratively from them.

Besides their central role in such national spheres as the economy and the polity, cities provide a living environment for their inhabitants. Since some 67 percent of the United States population resides in SMSA's ${ }^{2}$ the functioning of cities would be a vital concern even if their importance consisted solely of the quality of living enviroment which they provided their residents. While cities vary in their ability to provide all their inhabitants with a satisfactory environment, there has been a great deal of concern in the last few decades with the persistent inability of many of our langer cities to provide an adequate environment to their inhabitants.

It is obvious that this problem is reaching a critical stage in many of our larger central cities. As of 1975 New York City is said to be facing its worst fiscal crisis since the height of the Great Depression. The city's budget for 1975-1976 is smaller than the previous year's and calls for the termination of some 37,000 out

ILouis Wirth, "Urbanism as a Way of Life," The American Jourmal of Sociology, 44 (1938), No. 1, p. 8.

2U. S. Burreau of the Census, Statistical Abstract of the United States: 1973, (94th edition) Washington, D.C., 1973, Table 18, P. 18. 
of 330,000 city employees. ${ }^{3}$ This includes 11,000 jobs in education which are being cut at a time when the quality of New York City's school system is already well behind that found in the surrounding suburbs, and more than 6,500 policemen who are being fired ${ }^{4}$ despite the fact that central city crime has never been worse.

New York City's financial plight is an extreme case but it is a problem which in varying degree plagues local governments all over the country. A major cause of these problems is the hiatus between local resources and local needs. To a certain extent this problem is political and results from a changing definition of the appropriate role of government in local affairs. However, the problem is in lange part a financial one and arises from the movement of wealthy individuals and business firms out beyond the boundaries of the central cities. The political boundaries of the city--and, hence, the area within which the city can tax to raise revenue--is virtually always only a portion of the langer functionally interrelated area which might be considered to be the true urban unit. The problems of the cities, on the other haind, often involve processes which operate on a larger scale than the city itself. An obvious example of the latter being national population movements--particularly the movement of poor blacks from rual areas in the South into Northern urban centers.

${ }^{3}$ The Oregonian (Portland, Oregon), May 30, 1975, p. Al.
4he Oregonian (Portland, Oregon), June 13, 1975, p. A7. 
Many central cities are attempting to solve their financial problems by attracting wealthy suburban residents into the central city to live. The extreme ungency of the problems confronting local metropolitan govermments lends importance to the theoretical questions involved in the study of the decentralization within urban areas of high status residents. Our approach to this problem involves a study of the effect of particular aspects of central city areas on this decentralization. This is a small, specific aspect of the larger and more general situation, and first we need to examine what the current situation is, how it arose, and what are the implications which it poses for the quality of life in our cities. 
CHAPTER II

TRENDS IN SUBURBANIZATION AIND THEIR IMPORTANCE

I. OVERVIEW OF .TRENDS IN SUBURBANIZATION

General Trends

Before the advent of the industrial cities which resulted from the Industrial Revolution in the late $1700^{\prime}$ s, residential location in cities was usually spatially stratified by social class with the richest inhabitants at the center and the poorer inhabitants at the extremities. This is still the situation in many cities in the developing countries. In industrial cities the characteristic spatial stratification of residences by income has changed as advances in communication and transportation technology have made distance less of a factor in city structure. By the late nineteenth century the use of electric trolleys and trains was resulting in an early "suburbanization" of the wealthier members of society in outlying areas served by the expanding transportation networks. This trend expanded during the $1920^{\prime} \mathrm{s}$ as wider distribution of automobile ownership enabled the middle classes to locate outwards from town along the existing roads.

The percentage of the United States population growth which occurred in suburbs, or politically independent communities which are located within commuting distance to a central city, and which are ecomomically dependent on the central city, has increased steadily since 1900, while the percentage occuming in central cities has been 
dropping. The change in national growth patterns has been even more striking in nonmetropolitan areas, which between 1950 and 1970 experienced an absolute loss in population. 5 In 1970, for the first time, a larger share of the Anerican population lived in suburbs than Iived in either central cities or nonmetropolitan areas. 6 In the decade from 1960 to 1970 there was a 17 percent increase in the population of the nation's SMSA's, but 95 percent of this SMSA growth took place outside of the central cities. 7 The trend towards suburban expansion seems likely to increase, and Anthony Downs estimates that during the next two decades suburbs may capture as mich as 60 or 70 percent of the national population growth. 8

The Suburbanization of Business and Industry

With increasing improvements in transportation, such as the growing importance of trucks in overland shipping and the construction of vast road systems, the decentralization of central city residents has continued and has been joined by the decentralization of various commerical and industrial establishnents--which then leads to further movement of residents. The decentralization of employment has generally progressed furthest in the larger metropolitan areas. As of 1970, in nine of the fifteen largest metropolitan areas the suburban employment

5 Robert Lineberry and Ira Sharkansky, Urban Politics and Public Policy, (New York: Harper \& Row, Publishers, 1971), p. 22.

6John Kramer, "Introduction," North American Suburbs, ed. John Kramer (Berkeley: The Glendessary Press, 1972), p. Xiii.

7 Ibid., pp. xii-xiii.

${ }^{8}$ Anthony Downs, Opening Up the Suburbs, (New Haven: Yale University Press, 1973), P. 24. 
equalled on exceeded that found in the central city. ${ }^{9}$

This shift in employment results partly from the desire to provide goods and services to the growing suburban population. It has been suggested that on the average about half of the jobs in a given central city exist to supply the wants of the local population.10 Hence, as more of that population moves outwands, those jobs move with thern.

Another factor leading to the suburbanization of employment, besides the improving transportation technology, is the growth of automation. Automation often requires a single story layout. Cheaper land in the outlying areas then pulls firms outwards. The importance of automation lies in the fact that when one firm successfully automates the rest of the firms producing that product may no longer be able to choose whether or not to automate if they want to remain competitive. In some part the decentralization of employment also feeds off of the concurrent decentralization of population, since there is a growing labor pool in the suburbs, though this is probably a secondary factor. In addition, parking and driving congestion in central cities pushes firms to suburbanize.

The only three basic categories of employment in which the central cities are retaining or increasing their share of the metropolitan jobs are office work, service jobs, and government jobs. ${ }^{11}$

9Harold Peterson, "Trends in Inter-Governmental Relations," Suburbia in Transistion, ed. Louis Masotti and Jeffrey Hadden (New York: New Viewpoints, 1974), p. 98.

10Edward Banfield and James Wilson, "The City as a Setting for Politics," Cities and Suburbs, ed. Bryan Downs (Belmont, California: Wadsworth publishing Company, 1971), p. 35.

11 Anthony Downs, p. 11. 
Concentration of Minorities in the Central Cities

Suburbanization is predominately a phenomena involving affluent whites. While blacks constitute about 12 percent of the national population they are only 5 percent of the suburban population, and while they have been suburbanizing, they have not been suburbanizing fast enough to increase their proportion of the suburban population. 12 In contrast to this under-suburbanization of blacks, the percentage of the central city population which is black has reached 21 and is rising. ${ }^{13}$ This concentration of blacks in central cities is an outgrowth of the lange mignation of Southern blacks into Northern cities which flower ed after world war II and peaked in the 1950's. There are still large numbers of blacks moving into the central cities, but the number already there is now so lange that the main increment to the black central city population occurs through natural increase. Currently, the 56 percent of the black population which resides in central cities is over twice the percentage of the white population which resides in central cities. ${ }^{14}$

While blacks are the langest of the disadvantaged minorities, there has been a similar tendency for Mexican-Americans, Puerto Ricans, Ameri$c$ an Indians, and Cuban refugees to congregate in central cities. The langely poor, unskilled members of these minority groups do not gather in the central cities solely because of discrimination, but also to seek out the inexpensive housing and unskilled jobs available there. In doing

12Herbert Gans, "The Flight of the Middle-Class From the Central Cities," Masotti, p. 75.

13 Ibid., p. 75.

${ }^{14}$ Lineberry, p. 25. 
so they are following the path taken by several previous groups of immigrants who have managed to varying degrees to work their way up in the class hierarchy.

\section{THE PROLIFERATION OF METROPOLTTAN GOVERNMENTS}

\section{Defensive Incorporation}

While the groups which are suburbanizing desire different living conditions, the increasing influx of migrants to the outlying communities generally results in those individuals who have already settled incorporating their comnunity in order to avoid an uncontrolled rush of newcomers and the entrance of certain non-residential used which are viewed as harmful.

It is common, particularly in the langer metropolitan areas, for the central city to be completely hemmed-in by independent settlements which were hastily incorporated in onder to defend the interests of the local inhabitants. These defensive communities usually refuse to be annexed by the langer city unless the small community finds itself incapable of providing its residents with the services they desire at a reasonable cost, but at that point it is no longer to the central city's advantage to annex the small community and in some cases they have refused to do so.

This pattern, of settlements just outside of the city incorporating in response to the threat of annexation by the central city, has been increasingly common since 1900 and reflects changes which the $r$ epresentatives of rural and suburban areas have engineered in state laws making it harder for cities to annex while leaving it very easy 
for independent settlements to incorporate. ${ }^{15}$

Those built-up areas which are outside of the city and which are unincorporated are dependent on the county goverment for services. The relatively low level of services available from the county causes some built-up areas to favor annexing to an adjoining city. This is particularly true with sewer service, though improved fire and police protection, along with improved garbage collection are also important factors. ${ }^{16}$ However, many unincorporated areas continuously resist annexation to an adjoining city. Particularly in the case of large cities, annexation may be fought because fringe residents do not want to be taxed in onder to pay for socjal services for low and moderate income residents of the central city. Additionally, big city politics are often viewed as comoupt and something to be avoided. In general, attempts at annexation tend to be most successful when the residents of the suburb and the city are sinilar in terms of socioeconomic status. While efforts have been made to make it more difficult for new settlements to incorporate, this will not provide any relief for cities which are already surrounded by independent settlements. Moreover, the reapportionment of state legislatures which occurred in the 1960's has boosted the power of the suburbs in state governments and is likely to heighten resistence to the easing of annexation laws.

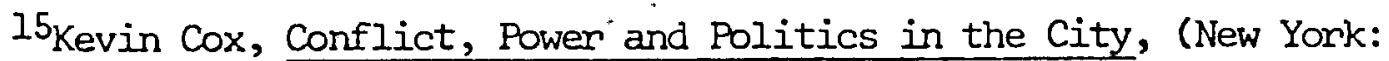
McGraw-Hill Book Company, 1973), p. 22.

16 Willis Miller, "An Evaluation of Methods for Controlling Urban Dispersal," The Nature and Control of Urban Dispersion, ed. Ernest Engelbert (Berkeley: The University of California Printing Department, 1960), p. 97. 
Once defensive suburbs have incorporated they eract zoning laws in order to defend their community against undesirables. These undesinables are things like dirty industries, the poor and non-whites. The defensive use of zoning can often be seen as suburban cormunities move rapidly to modify their zoning laws in order to keep out planned in-movements of an undesirable type. 17 Suburbs use zoning in onder to let in only relatively affluent people and thus ensure that the tax-rate will be low for relatively good services. This makes the suburbs even more desirable to the affluent who bid suburban land further out of the reach of the poor.

The fact that each of these governments is responsible for its own taxation and expenditures means that the increasing location of the wealthy and business and industry in the suburbs creates problems in the financing of the poorer municipalities. The main source of revenue in these local communities is through the levying of property taxes. As the wealthy and businesses have moved out, many of the older central cities find themselves with stationary or even declining tax bases. ${ }^{18}$ Moreover, since public property along with that of non-profit organizations and churches is not taxed, many cities which specialize in governmental or educational functions experience problems in raising revenue. 19 Since the social services provided in one community are 17 Cox, p. 53 .

18 Anthony Downs, p. 38 .

${ }^{19}$ In the City of New Haven, the location of Yale University, only a little more than half of the actual property within the city limits is on the tax rolls. Lineberry, p. 210. 
usually funded independently of those provided in neighboring communities it is possible for a badly-funded program in one community to limit the effectiveness of a good program in a neighboring community. This is perhaps clearest with such services as recreational services, health services, and police protection.

\section{Unequal Division of Resources Between Metropolitan Governments}

The residential decentralization occurring within metropolitan areas is not in itself a bad thing. Some criticism of the trend has focussed on the volume of productive agricultural land which is being converted to non-agricultural uses, but while it is true that the trend may seem regretable in view of widespread starvation in other parts of the world, there is no immediate lack of farmland in this country. A second criticism has been concerned that with the growing size of urban areas it will be impossible to provide open spaces for recreation which will be accessible to all of the population. But it seems unlikely that our cities will grind to a halt for lack of recreational facilities. A third complaint has been that residential decentralization results in higher per capita costs in the delivery of needed services. However, a study has suggested that the dispersal of the urban population doesn't necessarily result in more than "minimal" increases in the cost of services provided that long range planning is in effect. and that the new building occurs in reasonably centralized nodes as opposed to scattered freely around the umban fringe. ${ }^{20}$

${ }^{20}$ Robert Daland, "The Impact of Urban Dispersal on Local Government Costs and Services," Engelbert, p. 79. 
It is the presence of several independent incorporated municipaities in a metropolitan area which makes residential segregation by income important. Since each municipality is responsible for funding the services it provides, the movement of the wealthy to outlying communities while the poor are concentrated in the central city results in variation among cormunities in the ratio of their resources to their needs. We tend to think of this problem in terms of the affluence of the suburbs and the poverty of the central cities, but that problem is particularly true in the langer SMSA's. In SMSA's with a population under 250,000 it is the central cities which usually have the higher ratio of resources to needs. 21

The gap in earning power between the suburban residents and central city residents has been increasing over time. The median family income for central city residents fell from 88.5 percent of the median family income for metropolitan residents living outside of the central city in 1959 to 86.2 percent of the median family income for metropolitan residents living outside of the central city in $1964 .{ }^{22}$ However, these are aggregate figures and it shouldn't be thought that all suburbanites are affluent. Suburbs as a whole contained 67 percent as many poor people as did central cities in 1970.23

${ }^{21}$ Lineberry, pp. 29-30.

${ }^{22}$ Alan Campbell and Philip Meranto, "The Metropolitan Education Dilenma: Matching Resources to Needs," Bryan Downs, p. 340. ${ }^{23}$ Anthony Downs, p. 43. 
Suburbs vary widely and sone resemble central cities more than other suburbs. Some older suburbs--typically located relatively close in to the central city-resemble central cities in the deterionation of their physical plant and their growing concentrations of low-incone residents. One suggestion for classifying suburbs is Leo Schnore's division between employing suburbs and residential suburbs and a thind group of intermediate suburbs. Schnore bases this classification on the difference between their daytime and night-time populations. Residential suburbs are growing much faster than are employing subumbs. Schnore calculated in the mid-1960's that the median income of residential suburbs was more than $\$ 1,300$ greater than the median income in employing suburbs. 24

Reynolds Farley's study of the persistence of the socioeconomic characteristics of individual'suburbs suggests that the growing gap between the median income of suburban residents and median income of central city residents doesn't' result from a general increase in the income of subirban residents so much as from the differentially rapid growth of the more well-to-do suburbs. 25

III. THE INCREASING FISCAL STRAIN IN THE LARGE CENIRAL CITIES Costs Arising from the Concentration of the Poor and Minorities

The demand for expenditures in the central city has been increasing all the time. This results partly from the fact that the city is p. 179.

${ }^{24}$ Leo Schnore, The Urban Scene, (New York: The Free Press, 1965), 25Reymolds Farley, "Suburban Persistence," Kramer, p. 84. 
aging, and partly from the fact that the city is accumulating large numbers of low and moderate income residents who have come to depend on the city for a wide range of services. It is the concentration of those poor people Anthony Downs refers to as the "left-out" poor which is especially significant since they are the ones who have given up all hope of eventually rising out of poverty by conventional means, and who have turned their backs on middle class values and exhibit behavior which effects negatively those around them. ${ }^{26}$ with lange numbers of low-income individuals living in the same area the negative traits of one family can reinforce the negative traits of other families, and a culture of poverty can arise transmitting all sorts of defeatist, antisocial behaviors.

Other poor minorities have concentrated in the central cities in the past, and it has been for most of them a path up the class hierarchy. However, since the first part of this century changes have occurred in the economic and political structure of this country which have made such a "success story" unlikely for current minorities. In the first place, the umban economy no longer has as many openings as it once did for unskilled workers. . Secondly, the spread of unionization means that even relatively unskilled occupations are now unionized, and these unions often battle against the entrance of minorities. An additional change is the dismantling of the big city political machines. These political organizations used to distribute great numbers of low skill jobs as patronage to their supporters. Now these jobs are largely controlled by civil service, and those which are still available to 
distribute offer wages which usually haven't kept pace with the increases in the private sphere. ${ }^{27}$ This experience is all the more frustrating for contemporary minorities because of the exposure they have had to the great affluence enjoyed by many in this country.

It is the jobs which require only minimal education or special skills which usually suburbanize fastest. ${ }^{28}$ Yet the growing suburbanization of these jobs poses a handship for low-income individuals since they are less likely to have access to reliable inexpensive transportation. Moreover, the dispersal of both residences and employment throughout the subumban area means that public transportation is oriented towards serving downtown and is usually of little help in taking the poor out to suburban jobs. The result can be seen in studies in several cities which have shown that blacks tend to have substantially longer joumeyto-work trips than do whites. 29

Anthony Downs argues that the best way to open up suburban jobs to the central city poor is to provide low-cost housing in the suburbs so that low-income workers can locate near the jobs available there. Increased funding for mass transit will not solve the problem since mass transit systems become increasingly inefficient as a means of transmitting low-income workers to suburban jobs as the number of possible destinations and points of origin both increase. Alternatively,

$$
\begin{aligned}
& { }^{27} \text { Lineberry, p. } 81 . \\
& { }^{28} \text { Cox, p. } 62 . \\
& { }^{29} \text { Irid., p. } 64 .
\end{aligned}
$$


it would be risky to encourage the growth of new low-skill industries in the central cities since that goes against the forces which are leading to the dispersal of such industries. New low-skill industries wolld probably have to be continuously subsidized in onder to compete successfully with low-skill industries which have benefitted from the sayings available in a suburban location.

As long as low-incone families are concentrated in such large numbers in the central cities it is impractical to try and solve the fiscal problems of the central city by, attracting the wealthy back in. Middle and upper incone households do not just desire that an area be renewed physically and provided with efficient public services--though these changes alone would entail a lange investment--they also desire that the area be dominated socially and economically by middle and upper income households. This dominance is particularly important to households which have children. Therefore any successful attraction of middle and upper income households back into the central city depends on a policy of dispersal of the low-income residents currently living there. The money for changes of this scale is not available.

Suburbar Exclusion of the Poor

The concentration of the poor in the central cities is in part a result of their inability to afford suburban housing. While the cost of suburban housing is partly explained by the costs of construction, it is largely a result of suburban laws and regulations which ensure that the only houses which are built are houses which are too expensive for any but the wealthy to afford. 
Suburbs can refuse to zone any land for the construction of multiple-family dwellings, and can also zone for house lots of a minimum size--such as half an acre--which will force the building of an expensive house. In addition, suburbs sometimes manipulate their housing codes, such as by liniting the number of bedrooms a house can have, in order to limit the number of school-age children which a family will bring into the community. In taking these and similar actions the suburbs are clearly exceeding the original justification for zoning and other regulatory powers which was to protect the health and safety of the community. 30

Local housing codes can also restrict the housing available to those with low incomes. In 1967, 80 percent of all municipalities and townships with 5,000 or more inhabitants had their own housing codes. ${ }^{31}$ These housing codes are often so detailed as to specify types of material and methods of construction to be used. The failure of local governments to constantly revise these laws 'to incorporate advances in housing technology artificially bolsters the cost of housing. When one suburb uses these procedures it can have the effect of raising the cost of land in an adjoining, unregulated suburb, keeping the poor out of that suburb also.

New suburban housing could be built which relatively low-income families would be able to afford. Anthony Downs has estimated that by using the latest in construction techniques it would be possible to

${ }^{30}$ Principles and Practice of Urban Planning, ed. William Goodman (Washington, D.C.: International City Managers' Association, 1968), p. 404 .

${ }^{31}$ Anthony Downs, p. 49. 
build housing for a family of four-the same size as the average housing for a family of four in Moscow--for less than 40 percent of the cost of the least expensive new quadriplex units currently available in lange metropolitan areas. 32

Influence of the Federal Government on Eoonomic Integration

The Federal Government has exerted only light pressure on suburbs to modify these practices. The Department of Housing and Urban Development currently promises to give first priority in sewer, water, and open-space grants to communities that relax their zoning restrictions on low-income housing. ${ }^{33}$ The Department hopes that if enough restricted suburban land is opened for buịlding low-income housing that private corporations will invest in the production of low-cost prefabricated housing, and through mass-production the cost of such housing will decline considerably. So far this program has not been noticeably successful. A major factor retarding Federal efforts is resistance by the President. Former President Nixon had declared he would resist efforts to use the legal or financial influence of the Federal Government to compel suburbs to accept low or.modenate income housing against their wishes, ${ }^{34}$ and President Fond has not drawn back from that position.

Effect of the Trickle-Down Housing Policy.

The inability of the paor to afford housing which other members

${ }^{32}$ Ibid., p. $50 . \quad 33$ Peterson, p. 113.

${ }^{34}$ Charles Williams, "Opening Up the Suburbs," Masotti, pp. 151-152. 
of the society consider socially acceptable is a problem comnon to all modern industrial nations. In most of these nations the government attempts to solve this problem by subsidizing the construction of large amounts of housing for low-income individuals. But in this country there is a traditional refusal to consider governmental action to alleviate a problem until it. is clear that free enterprise cannot solve it. The govermment has refused to directly subsidize much housing for low-income individuals and has instead tried to improve the housing situation through stimulating the construction of new housing for the relatively affluent. This "trickle-down" approach is based on the assumption that if new housing is constructed for middle and upper income individuals to occupy, the hoúsing they vacate will be purchased by individuals who are slightly less well-to-do, whose housing will in turn be purchased by individuals still less well-to-do than themselves, until eventually everyone has acquired better housing.

The trickle-down process is not functioning effectively. A major drawback is that not enough houses are being built for the middle and upper income groups to lower the price of housing available to other groups. One explanation is that the affluent no longer spend the same proportion of their income on housing as they used to, because of a decrease in their tendency to flaunt their wealth. ${ }^{35}$

Even if the trickle-down process were working effectively it would have certain undesirable consequences. Since the process emphasizes the building of expensive housing it results in the creation of entire

35R. J. Johnson, Urban Residential Patterns, (London: G. Bell and Sons, Ltd., 1971), p. 176 . 
neighborhoods consisting of housing in the same general price range. As a result the city is divided into areas which are occupied by families with similar incones. While it may be true that most of the families themselves want it that way, and like not having any distinctly poor people in their area, it is questionable whether this result is desirable in terms of langer social values. It means that the great bulk of the poorest people in the city are crowded together in the worst housing. There is no question but that the crowding together of these poor families worsens their condition.

Suburban Exploitation of the Central City

The political independence of the suburbs from the central city imposes costs on the central city which are in addition to those arising from the exclusion of the poor from the suburbs. In particular, central city finances are strained by the need to provide services to suburban residents who comnute into the central city to work and to make use of the cultural facilities. In 1965 the budgets of the 37 largest central cities included non-educational (municipal) outlays which were over 75 percent greater per-capita than those in their surrounding suburbs. ${ }^{36}$ To a certain extent this is a result of the greater age of the central city, and yet a study has shown that when the age of the central city and the size of the central city population are controlled for, there is still a positive relationship between the per-capita cost of municipal services and the size of the city fringe population. ${ }^{37}$

36Anthony Downs, p. 39. ${ }^{37}$ Dalarid, p. 80. 
While some cities such as New York City have instituted sales taxes as a means of taxing suburban commuters, the two most important central city taxes aimed at commuters are paycoll taxes levied on everyone who works in the central city, and income taxes levied on everyone who works in the central city. However, Herbert Gans suggests that even when central cities levy taxes on commuters, the taxes typically fail to cover the full cost to the city of providing the cormuters with their places to work, shopping areas, and cultural facilities. 38

Another example of suburban exploitation of the central city is the practice of baming non-residents from the use of some suburban parks, or else the levying of fees for their use by non-residents. In contrast, central cities genenally provide such facilities without regand to the residence of the user. Some central cities have bargained with thein suburbs for money to finance the provision of central city services which are open to the use of the whole area. But such bargaining takes the form of begging on the part of the central city and is very unlikely to ever be a satisfactory answer.

It is sometimes suggested that the movement of the middle-class groups to the suburbs is draining the central city not only of potential tax revenue but also of those individuals who are most likely to be interested in and active in improving the cities. However, Gans suggests that this assumes that the active middle-class individuals are working to further everyone's interests, whereas in fact the organizations middle-class individuals join tend to work in support of middle-class interests. ${ }^{39}$ Furthermore, Gans maintains that it is a mistake to assume ${ }^{38}$ Gans, p. $52 . \quad{ }^{39}$ Ibid., p. 51. 
that just because middle-class individuals move to the suburbs where they may be barred by reason of residence from various elective and appointed offices in the city, they are no longer exerting an influence on central city politics.

Tax Strain in the Central Cities

In order to meet these burdens the central cities are forced to levy ever higher taxes on property, and to introduce non-property taxes such as municipal taxes on income or sales. The difference between the tax burden on central city residents and that on suburban residents can be seen in 1965 data which show that in the 37 langest central cities local taxes averaged 7.6 percent of the personal income of their residents, while outside of the central cities, they averaged only 5.6 percent of the residents' income. ${ }^{40}$ Moneoven, the large central cities - appear to be falling further behind their suburbs in terms of how adequate their tax base is to their speriding obligations.

Central cities are prevented from taking full advantage of their tax potential by threats from the middle-income individuals who have remained in the central city to move outwards and further decrease the city's tax base. In order to avoid the flight of additional middleclass residents the central cities sometimes purposefully under-assess the value of houses in middle class aneas for property tax purposes. 41 There is also ample evidence of central cities spending disproportionate amounts of money on their middle-income individuals in areas ranging from road repain to school financing. 42

$$
\text { 40 Anthony Downs, p. 39. 4I Cox, p. 13. } 42 \text { Ibid., p. } 74 .
$$


Both middle and upper-income groups and business establishments have made widespread use of the threat to move elsewhere to secure favorable treatment from central city governments. In responding to these threats central city governments probably overestimate the chance that the complainers will actually move, since the evidence shows that local tax rates are not actually that prominent a factor in the locational decisions of eithen individuals or businesses. 43 Moreover, many middle-income individuals in particular consume a langer amount of city services than their taxes pay for, and their contribution to the financing of the city is probably exaggerated. 44

Besides this favorable treatment, central cities have tried other policies to lure the affluent back in. Prominent among these are the construction with urban renewal funds of expensive high-rise apartments for those who have a particular interest in the cultural facilities offered in central cities, or else who want to be close to their downtown jobs, and the highway construction program which has attempted to keep the central city businesses competitive with outlying shopping centers. Since there is usually no additional low-cost housing built to replace that which is demolished, the projects increase the crowding in low-income areas and boost the cost of low-income housing. These hardships have not been eliminated by the Fedenal programs seeking to.insure that there will be adequate housing for individuals displaced by highway or renewal construction programs. 45

${ }^{43}$ David Shirley, "Urban Decentralization and Local Government Revenues," Engelbert, p. 86.

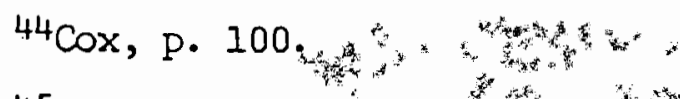

45 Mare Fried, "Grieving for a "Lost Hontert Psychological costs of Relocátion," "Urban Renewal, ed Jâmes Wilison (Cambridge: The M.T.T. Press, 1967) 
IV. THE DECLINING QUALITY OF CENTRAL CITY PUBLIC SC:HOOLS

The quality of suburban schools is the leading reason given for the suburban move. 46 The declining quality of central city schools pushes middle and upper-income residents to the suburbs, which leads to still further decline in central city schools. Hence we shall consider the problems of central city schools at some length.

The Increasing cost of Central City Schools

Costs Involving Staff and Physical Plant. The fiscal strain op the central cities is aggravated by the fact that central city school systems are usually more expensive to administer than subumban school systems. Yet, since central cities usually offer a wider variety of other public services, education typically forms a langer proportion of the budget in the suburbs, and per-pupil expenditures in suburban schools consequently tend to be considerably langer than per-pupil expenditures in central city schools. ${ }^{47}$ part of the greater expense of central city schools derives from the greater capital costs involved. Buildings tend tó be relatively old in central city areas and in need of expensive maintenance. Moreover, the difference between central cities and suburbs in land costs means that any new construction will be much more expensive in central city areas. Vandalism is also more of a problem for central city schools, and in the worst areas can amount to a considerable sum of money.

Probably the main cause of higher operating costs in the central 46 Ibit: , p. $86 . \quad{ }^{47}$ Anthony Downs, p. 39. 
city schools is the higher cost of the teaching staff. 48 Finst-rate teachers may refuse to work in central city schools, and those that will work may demand higher wages than from a suburban school. A final problem has been the closure in recent years of many central city parochial schools, increasing the number of students to be educated by public schools.

Costs Arising from the Concentration of Disadvantaged Students. The burden on the central city schools is increased by the fact that they include a much higher proportion of children who are disadvantaged in terms of such factors as the income level and educational background of their parents, the stability of their families, and the environment of their home life. All 'of these are factors which effect a student's initial preparation for school and possibly exert a continuing effect thereafter.

The growth in the proportion of non-white students--many of them disadvantaged--in the central city schools is greater than the growth which has occurred in the proportion of non-whites in the central city population. This is because of the greater size of the average nonwhite family, the tendency for whites raising families to live in the suburbs if they can afford to, and the greater tendency: of whites to send their children to private or parochial schools.

As increases occur in the proportion of a school's children who are disadvantaged, the middle and upper-incoine parents tend to move with their children to the subumbs in order to trin and assure that their children will grow up around ather children whose partents have values ${ }^{48} \mathrm{Cox}, \mathrm{pp} \cdot 32-33$. 
sinilar to their own. Interracial violence in schools which are integrating may also play a part. Yet it would be easy to overestimate the influence of intermacial violence because of the great deal of media coverage given to particular cases growing out of the integration of public schools. Curmently only about 1 in 25 white suburbarites mentions racial problems in central city schools as being his reason for moving. ${ }^{49}$ However, widespread busing to achieve integration may increase this proportion if the busing is accompanied by recurrent violence.

Potential Solutions

Alleviating Funding Problems. It is clear that central city schools are not providing satisfactory learriing experiences to the great numbers of disadvantaged children they serve. The inmediate solution would seem to be to increase the expenditure on central city pupils. But it, is not clear where this money will cone from in view of the disjunction between resources and needs which plagues many metropolitan school districts. And even if the money could be raised it is not clear that meaningful improvements would be obtained. Previous projects which have tried to improve the education of disadvantaged students through increased expenditures have not been particulanly successfur. 50

One hope that the fiscal dilemma of the central city schools may be solved is the recent court rulings, such as Sermano v. Priest,

49 Robert Schwartz, Thomas Pettigrew, and Marshall Smith, "Fake Panaceas for Ghetto Education," Social Change in Urban America, ed. Max Bimbaum and John Mogey, (New York: Hamper \& Row, Publishers, 1972), p. 92.

50Campbell, p. 348. 
in which the California Supreme Court held that financing schools mainly from local property taxes was unconstitutional because it made the quality of a child's education a function of the wealth of his parents and their neighbors. Property taxes are also attacked on the grounds that the extreme mobility of contemporary families makes it illogical to finance local education through a property tax since the education which the children receive will not benefit the local community. Integrating the Schools. Studies have shown that the single best indicator of a child's educational achievement is the income level of his parents. 51 This is important in view of the division of our cities into areas whose residents have similar incomes, and the fact that the single best indicator of a community's expenditure for both school and non-school services is the income level of the community's residents. 52

The Coleman Report implies that busing low-income children to middle-income schools will improve the education of the poor children more than could be achieved by any practical program of intensified inghetto schooling, though it is clear that this change alone would not eliminate the difference in achievement between the two groups of children. 53 Busing to achieve racial integration in schools furthers socioeconomic integration since many non-white school children come from relatively poor families.

5IIbid., p. 343. 52Ibid., p. 345. 53Anthony Downs, pp. 33-34. 
An alternative means of securing racial integration in public schools, and, hence, of securing greater socioeconomic integration, is trrough the construction of "education parks" or schools which are much langer than current schools. Because of their langer errollment area these schools would be more representative of the city's different population groups. However, this approach can not hope to integrate a city's school system unless the central city and its concentration of disadvantaged groups is not too large. Additionally, both busing and the creation of education parks go against the current trend in large city school systems towards the decentralization of control over local schools. This trend towards local control is bound to conflict with any attempts to establish a metropolitan-wide redistribution of students.

V. SOLUTIONS FOR THE HIATUS BETWEEN RESOURCES AND NEEDS

Metropolitan Consolidation

One possible remedy for the unequal distribution of municipal resources and municipal needs is metropolitan consolidation, or the creation of a single government for the entire metropolitan area as has been done in Indianapolis, Nashville, and Jacksonville. Such consolidation would provide financial benefits to the area considered as a whole. A uniform tax policy would mean that each community would not be tempted to try and attract industry away from the others through offering tax breaks or other incentives. In addition, there are economies of scale in the provision of some public services, notably water and sewage disposal.

A problem with metropolitan consolidation as an aid to our langer 
central cities is that the transfer of benefits wich is envisioned is often heavily weighted in favor of the relatively poor central city. In these circunstances it is hard to get subumban voters to agree to consolidation. More suburban voters would probably support consolidation if they knew that they could not otherwise escape the negative effects their policies have on other municipalities.

Proposals for a radical reorganization of metropolitan governments are usually strongly and effectively opposed by those individuals who have a stake in the present organization of local government. Many local politicians, for instance, oppose consolidation. Advocates of consolidation, on the other hand, tend to be relatively weak and disorganized in their support, appealing less to the easily understood arguments of their opponents, and more to vague promises of more efficient government.

In central cities where blacks have control of the government or are a sizable proportion of the electorate, blacks usually oppose consolidation because it would diminish their power. They would rather retain control of a financially troubled city, than merge with the affluent suburbs but lose control of the local budget. In fact, no survey of local voter attitudes towards consolidation has ever found a majority of a city's black population in favor of it. 54 Black politicians in central city governments usually support the idea of Federal revenue sharing with funds directed straight to the local level as the best solution to metropolitan financial problems. 55

54Lineberry, p. 141. 55Anthony Downs, p. 143. 
Some progress towards metropolitanization may result from pressure by the Federal govermment. Sevenal Federal grant programs require that areas receiving money draw up a metropolitan plan. These requirements have resulted in the drafting of a lange number of metropolitan plans, but it is still too early to tell how effective these plans will be in regulating further development.

Opening the Suburbs

A second solution to the problem of central city financing would be to open up the suburbs to low and moderate-income residents. The 1968 National Advisory Commission on Civil Disonders advocated this policy in combination with large-scale upgrading of ghetto areas. ${ }^{56}$ Any such opening of the suburbs would have to effect all of a central city's suburbs at the same time and to approximately the same extent. This is necessary in onder to limit the effect of the change on suburban property values, since concern over property values is a major focus of arguments against opening up the subumbs. If the change was only to effect some suburbs, each suburb would battle violently to see that it wasn't chosen.

In order for any policy of opening up the suburbs to be acceptable there would have to be controls over the number of low-income households and their distribution in the suburbs. If middle-class values lost their dominant position in the local institutions the middle-clas's households could be expected to move out. Precisely what number of low-income households could safely be allowed inta a given middle-class

$56_{\text {Report }}$ of the National Advisory Commission on Civil Disorders, ed. Otto Kerner, et. al., (New York: Bantam Books, 1968). 
suburb is not known. However, Anthony Downs suggests that to ensure middle-class dominance the percentage of middle and upper-income households in the integrated suburb would have to be well over 50 percent. ${ }^{57}$ Many suburbanites oppose opening up the suburbs on the grounds that the low and moderate-income families allowed in to suburban areas would bring with them the whole range of undesineable behaviors associated with the ghetto. But this danger is not necessarily as great as subumbanites seem to feel. Those central city poor who made the move would probably possess more dedication to middle-class values than is associated with ghetto residents in general. Hence, they would be likely to exhibit fewer undesirable behaviors than ghetto residents in general. In addition, much of the undesirable behavior associated with the ghetto undoubtedly results from the interaction there of large numbers of deprived individuals. It is not necessarily true that low-income individuals would act the same in middle-class surroundings as they act in the ghetto environment.

Some central city leaders oppose opening the suburbs on the grounds that it would be the most desirable low-income households which made the move to the suburbs, leaving the most deprived still living in the central city. This would only increase the bunden of problem families on the central city. But on the other hand the central city would be bound to benefit somewhat from the reduction in the absolute number of low-incame households.

In 1969, Massachusetts took a step towards opening up suburbs by passing a law which provided that duming each of the succeeding five years each community must make at least 0.3 percent of ițs vacant 
land available for the construction of low and moderate-cost housing. 58 This is one of the few moves which have been made to open the suburbs. However, another approach which has been suggested is to pass laws "making it illegal for any corponation hiring a significant number of workers to locate in a community where the price of local housing was more than the comporation"s employees could afford. 59 This would prevent relatively affluent suburbs from attracting industry out of the central city while denying residences to the industry's service-consuming low-income workers. If this nation is to achieve its stated goal of a decent home for each family it will be necessary for vast amounts of low and moderateincome housing to be built in the suburbs since there is not room for it in most central cities, and central city governments are more interested in trying to transfer what little open land is left into middle and upper-income homes. A positive result of successfully opening the suburbs would be greater ease in passing consolidation measures since there would be less clear-cut socioeconomic divisions between central cities and their suburbs.

In the absence of effective laws to open suburbs to low and moderate-income residents, the slow spread of the less affluent out of the city may result in a perpetuation of the old spatial split between the affluent and non-affluent. Individuals with middle and upper-incomes will gravitate to the newer, lower density suburbs further out from the central city, while the older, higher density suburbs closer in to the central city will be taken over by individuals with low and moderate58 Willians, p. 145. ${ }^{59}$ Tbid., p. 144. 
incones. As this trend progresses, suburbs which become dominated by those with low and moderate incomes will be no more able to provide their new residents with quality social services than the central city government had been. Hence in the absence of some kind of corrective action the political fragmentation in metropolitan areas virtually guarantees a perpetuation of the hiatus between resounces and needs which currently plagues our local level of government.

\section{SUMMARY}

In this chapter we have reviewed various facts of contemponary suburbanization in some detail. In making this review we have tried to briefly convey the extreme complexity of the intermelationships which are involved in the process. We have also tried to convey the great significance which the class-selective nature of this process holds for the, successful "functioning of the many local governments which presently typify our metropolitan areas. Because of the complexity of this situation there are numerous questions whịch might be addressed by research. Our study will focus on the class-selective nature of the process and will attempt to further our understanding of some theoretical issues involved in explaining the decentralization of high-status residents within urban areas. 


\section{THEORETICAL ISSUES INVOLVED INN INTTEGRATING THE HISTORTCAL AND STRUCTURAL THEORIES OF URBAAN FORM}

Our study is an addition to the attempt in urban journals to distinguish between two "different theoretical perspectives on urban form and to discover how they can be integrated to provide a more adequate description of the urban world. Perhaps the earliest concern with the difference between the two perspectives is to be found in an article by William Alonso in which he labels the earlier theory as the "historical" theory of urban form and the more recent theory as the "structural" theory of urban form. 60

Alonso uses the label historical theory to refer to theorises such as the ones put forward by Ennest Burgess and Homer Hoyt which predict the rich will live at an increasing distance from the center of the city with the passage of time. The distinguishing idea of the historical theories of urban form, according to Alonso, is the idea that the rich move outwards in response to the aging of central city housing as they seek open land on which to build new homes.

In contrast, the structural theory of urban form explains the outwand movement of the rich on the basis of a trade-off between desine for land and desire for accessibility. The simplest formulation of the

60William Alonso, "The Historic and the Structural Theories of Urban Form: Their Implications for Urban Renew," Land Economics, XL (1964), Pp. 227-231. 
structural model, which we will expand on later, argues that the desire for low density living is relatively constant across social classes. Then, since the rich are buying a larger quantity of land than the poor, the added commuting costs the rich incur through buying suburban land are less relative to their savings in cheaper land than is true for the poor.

Yet, Alonso's presentation of the contrast between the historical and structural theories is inadequate. In the first place, the idea that the rich decentralize in a process of flight from the obsolescence of central city housing does not appear in the literature as a self-contained explanation of the decentralization of the rich as Alonso seems to imply when he labels it as a theory and contrasts it with the structural theory. In the second place, it is misleading to attribute the idea which Alonso labels the historical theory to either Burgess or Hoyt. Burgess's concentric zone theory is the classic theory of urban form. Burgess was interested in the process of urban expansion. His zonal theory depicts the city as a series of five concentric circles with the central circle occupied by the central business district (CBD). 61 Burgess felt that the four residential zones formed a sequence so that the socioeconomic status of the residents of each zone was higher than that of the residents in the next innermost zone and less than that of the residents in the next outermost zone.

Burgess suggested that the zones of varying socioeconomic status become differentiated during the process of city expansion. He did not clearly specify why this differentiation occurs, but he implied that

61 Ermest Burgess, "The Growth of the City: An Introduction to a Research Project," The City, ed. Robert Park, Ernest Burgess, and R. D. Mckenzie (Chicago: University of Chicago Press, 1925), pp. 47-62. 
the zones resulted from a tendency for people of sinnilar class position to cluster together because of the greater ease with which feelings of cormunity arose among individuals who were of the same socioeconomic class. 62 These zones were than felt to inevitably grow outwards through a process of invasion and succession as a result of competition for central city land arising from both the continuous influx into the central area of the city of low status residents and the concomitant conversion of central land and buildings to non-residential uses. Hence, while Burgess felt that the rich would increasingly decentralize over time he did not view the obsolescence of central city housing as a major cause of this movement. Indeed, Burgess's position mone closely resembles the structural theory of urban form than the historical theory.

Homen Hoyt's sector theory was also listed by Alonso as an example of an historical theory of urban form. Hoyt's sector theory was an attempt to revise Burgess's zonal theory in view of evidence that the main pattern of variation in the socioeconomic status of city residents is not in a zonal pattern outwards from the $\mathrm{CBD}$, but that residences of particular socioeconomic status levels tend to extend outwards from the $\mathrm{CBD}$ in a sectorial pattem. ${ }^{63}$ While Hoyt pointed out that the socioeconomic status of residents in a particular sector did not necessarily rise with increasing distance from the $\mathrm{CBD}$, he felt that it usually did.

Hoyt listed several factors which affect the direction of growth

62Johnston, p. 69.

63Homer, Hoyt, The Structure and Growth of Residential Neighborhoods in American Cities, (Washington, D.C.: Federal Housing Administration, 1939). 
of the sectors by exerting a pull on the high rent district. Examples are the layout of the fastest existing transportation lines, the homes of the leaders of the community, highi ground which is free from the risk of flooding, etc. Important for us is Hoyt's conclusion that high rent districts tend to grow towards the section of the city which has open country beyond, and that this growth tends to continue in the same direction for long periods of time. It is true that Hoyt explains this process in terms of the desire of the rich for open land on which to build new homes, and yet this factor is only one of several which Hoyt sees as influencing the decentralization of the rich. Hence, while Hoyt accepts that the rich are moving further outwards with the passage of time it is an ovensimplification to cite him as an example of what Alonso calls the historical theory of urban form.

While interest in the effect which the obsolescence of central city housing exerts on the location of a city's high status residents does not enter into the early "writings: on urban form as clearly as Alonso implies, the variable has come into greater prominence with recent attempts to empirically test traditional generalizations about urban form. In 1963 Leo Schnore published a study in which he investigated the relative effects which the population of an urbanized area and the number of years since its central city reached a population of 50,000 exerted on the differential in socioeconomic status between the city and its subumbs. ${ }^{64}$ Schnore concluded that the age of the central city was the best predictor of the status differential: in

64 Leo Schnore, "The Socioeconomic Status of Cities and Suburbs," The Urban Scene, ed. Leo Schnore (New York: The Free Press, 1965), pp. 203-221. 
unbanized area with older central cities the suburbs tended to rank higher on measures of socioeconomic standing, while in urbanized areas with newer central cities the opposite was true. Schnore speculated that there ane two possible explanations of the significance of city age in the decentralization of high status residents. The first is the actual aging of the central city's housing structures, while the second is the competition which non-residential land uses exent on central city land. These two explanations correspond to Alonso's formulation of the historical and structural theories of urban form. Yet for Schnore they are only hypotheses and he makes no attempt to test them.

Schnore not only made explicit any notion which Bungess might have had of the effects of the aging of a central city's housing, he also reformulated Bungess's notion of the process of the invasion and succession of different socioeconomic groups to delete population pressure in the inner zones as an active cause. In addition, Schnore suggested that competition for central city land is of declining importance in the decentralization of the rich as advances in transportation technology have freed many non-residential land uses from the need for a central location.

Schnore's deletion of Bungess's emphasis on population pressure in the central zones can be traced to demographic changes which had occurred since Burgess oniginally formulated his theory. By the time Schnore was writing, poor migrants from European countries and poor blacks from mual areas of the South were no longer flowing into the central areas of our cities the way they did in earlier periods. Not 
only were rnigrants to our cities less in number and higher in social status than they were during earlier periods, they increasingly bypassed the central areas of our cities altogether and located either in the outer areas of our cities on even directly in the suburbs themselves.

In 1972 Avery Guest published a study in which he examined the differences between the historical and structural (termed "synchronic" or "cross-sectional" by Guest) theories of urban form, and in which he attempted to test a more sophisticated version of the historical theory. 65 While Guest's conception of the structural theory is the same as is Alonso's, Guest's conception of the historical theory is radically different. Guest uses the term historical theory to refer to theories which explain the outward movement of high status residents in terms of competition for central city land, and which then attempt to explain the differing intensities of competition for central city land in terms of historical factors in the growth of the city. Hence Guest depicts the two theories as much more similar than does Alonso: for Guest the historical theory is just the structural theory to which knowledge of past causes has been added. This formulation of the two theories seems more adequate than Alonso's, for Guest recognizes that in practice the two perspectives are almost always found in combination with one another. The problem then is not one of testing to see which theory is the right one, but one of devising how these approaches can

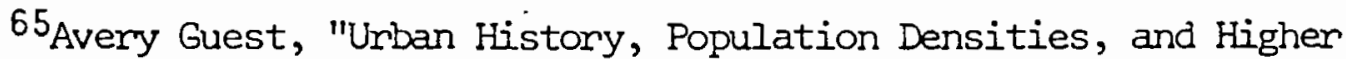
Status Residential Location," Economic Geography, 48 (1972), pp. 375386 . 
best be integrated.

Guest considers Schnore as the leading exponent of the historical approach and attempts in his study to explicitly test some of the hypotheses which Schnore offered. In particular, Guest explores the effect which changes in transportation technology have exerted on the intensity of competition for central city land and thence on the decentralization of high status residents. As his measure of the decentralization of high status residents Guest examined 1960 Census tract data for 37 SMSA's to find the change that occurred with increasing distance from the $\mathrm{CBD}$ in the median years of education for persons 25 years and over. Guest then regressed this variable on a measure of each city's population density gradient, with the density gradient perceived as an approximate measure of differences in land use intensity between centers and outskirts.

Thus far Guest's theory is a structural explanation of urban form. What makes Guest's theory an historical theory is that he then clains that a city's density gradient is determined by the amount of growth which the city experienced during eras when different modes of transportation were dominant. As a measure of this effect Guest computed the amount of growth which the cities experienced in each of three transportation eras, and then investigated the effects which this growth exerts on the density gradient in 1960, and on the decentralization of high status residents independent of the effect of the density gradient. Guest demonstrates that growth which occurred before the advent of the streetcan era is associated with relatively steep density gradients and relatively decentralized high status residents. In con- 
trast, growth wich occurred during either the streetcar or automobile eras was associated with flatter density gradients and with less decentralization of the high status residents.

These results are used by Guest to attack the use of city age as a variable in studies of urban form, since such a variable combines the differing effects exerted by growth occurring during each of the transportation eras. In support of his attack, Guest reports a study of 46 central cities which showed that city age as measured by the time since the city achieved a population of 50,000 had virtually no effect on the density gradient when other variables were controlled for. 66 Yet Guest does not completely succeed in discrediting the use of city age, for city age can function as an indirect measure of other processes than just changes in the intensity of land use. For example, Lee Haggerty used city age, in a study of the decentralization of high status individuals, as an indicator of the aging of the central city's housing. 67 After all, Guest's model with its reliance on the density gradient and population growth in three transportation eras only succeeded in explaining 31 percent of the variance in the status gradient. ${ }^{68}$ There

66 R. F. Muth, Cities and Housing, (Chicago: University of Chicago Press, 1969), pp. 135-183 Quoted in Guest, p. 379.

67 Lee Haggerty, "An Empirical Assessment of Urban Renewal Theory: Density vs. Age of City," unpublished manuscript, Department of Sociology, Portland State University.

68Guest tested his model for both 1950 and 1960. The 1950 model explained 31 percent of the variance in the status gradient, while the 1960 model explained 27 percent. Guest, p. 386. 
are clearly other forces at work. It is possible to presume prenaturely that city age is of no use as an indirect measure of the operation of these forces. Though any study in which age plays an important part is obliged to provide a theoretical rationale for the variable's effects. Guest interprets his results as supporting Schnore's hypothesis that improving transportation technology is lessening the influence which competition for central city land exerts on the decentralization of high status residents. Yet Guest is puzzled by the relatively strong affects which the amount of growth in the central city population in each transportation era exerts on the decentralization of high status residents independently of the influence exerted by the density gradient. Guest's explanation is that central city population growth in earlier periods affects contemponary patterns of housing deterionation and industrial location, which in turn affect the location of high status residents. Schnore had also hypothesized the influence of these two factors, yet neither he nor Guest offer any empirical support for the hypothesis. We will attempt to fill this gap in the literature by incorporating a measure of the hypothesis.

Relating the outward movement of high status residents to the aging of a city's housing has an intuitive appeal. Since high status residents tend to own their houses they have a considerable financial stake in the value of their housing. The individual owner has an interest not just in the upkeep of his house, but in the trends in housing upkeep in the entire neighborhood in which it is located. Once an individual's house has aged to the point where he no longer considens it acceptable housing he is faced with a choice between building new 
housing on the same or vacant land, or extensively remodelling the existing dwellings. Since the value of his housing depends partly on the quality of the housing around it, and since the surrounding housing is also aging and may or may not be rehabilitated, in many cases the individual can not afford to assume that his neighbors will all reinvest in the upkeep of their present homes. Hence, the rational choice in these circunstances is to build a new house, particularly in an area which is currently being developed so that the house will be surrounded by others which are also new. These elements of the process by which individuals come to view their present housing as obsolete and decide to move into new housing are referred to in the urban literature as depreciation and locational obsolescence. In addition, technological obsolescence, style obsolescence, and site obsolescence have been suggested as factors affecting the suitability of a particular home. ${ }^{69}$

This sort of reasoning has been attacked for its conclusion that residential areas inevitably deterionate over time. Walter Firey in particular has attacked theorists of urban form for their assumption that we can study physical space in urban areas while ignoring the cultural significance which often attaches to particular locations. Firey studied aspects of the land use in Boston which couldn't be explained by existing models of urban form. He then generalized his results to suggest that particularly in older American cities we often "find a symbol-sentiment relationship which has exerted a significant 69Johnston, pp. 96-97. 
influence upon land use."70 Yet, however useful Firey's work may be in explaining aspects of land use which can not be explained by ecological principles, it is clear that cultural values do not determine the overall layout of the urban pattern but act to modify the more basic forces which are at work.

We will describe our study after first expanding on the description of the structural theory which we offered earlier. Probably the basic assumption underlying the structural theory is that the demand for land is constant across social class. Alonso argues that it is, and that the demand for land is in this country ". . a deeply ingrained cultural value, associated not only with such functional needs as play space for children, but also with basic attitudes toward nature, privacy, and the mearing of the family." 71

Not everyone agrees that the demand for land is so widely shared. In the last few decades, several writers have emphasized the attachment many residents of high density low-income areas feel for their area. Firey pointed out in his study of Boston that the out-migration from inmigrant ghettos was selective for those--particularly the children of immigrant parents--who have turned thein backs on the immigrant values. Of course, inmigrant ghettos no longer form as large a portion of bigcity slums as they once did. In terms of numerical importance, immigrant ghettos have been replaced by black ghettos. Yet Firey's explanation of the selective out-mignation of ghetto residents in terms of their

70 walter Firey, "Sentiment and Symbolism as Ecological Variables," Studies in Human Eoology, ed. George Theodorson, (Evanston: Row, Peterson and Company, 1961), p. 258.

${ }^{71}$ Alonso, p. 230. 
attachment to the local ghetto culture remains a valuable insight.

Other studies have substantiated the attachment which many slum dwellers feel for the area's subculture. It has been suggested that far from wanting to flee the noise and congestion which color the middleclass conception of sluns, "the majority of slum residents experience . . . the residential area (as) the region in which a vast and interlocking set of social networks is localized."72 Further, it has been argued that the working-class slum dweller's attachment to his residential area involves an "intensity of meaning" and "basic sense of identity" which is "profoundly at variance with typical middle-class orientations."73 These residents often feel a deep sense of loss when they are forced as by urban renewal to move elsewhere. Hence the poor may well desire lowdensity housing less than the affluent. But in so far as this is true it only makes the structural model more persuasive, since cheap land in the suburbs would then lose much of its appeal to the poor. The structural model might be called into question if it was demonstrated that the poor desired low-density housing much more than the affluent, but no one seems to have seriously suggested this.

Another possible error is to assume that all high status individuals desire low-density housing. It has become fashionable to argue that city living is desireable not only for retired professional people who want to be near the cultural facilities available there, but even as locations for raising children. Probably the main exponent of this view has been Jane Jacobs, though Richard Sennet has also angued it.

$$
{ }^{72} \text { Fried, p. } 362 . \quad{ }^{73} \text { Ibid., p. } 362 .
$$


If the publication of their two books were to indicate an increasing valuation of high-density living on the part of high status individuals, the structural theory would predict a decrease in the outwards expansion of our cities.

Jacobs arrives at her defense of high-density Iiving through her study of the "ubiquitous principle (of) . . the need of cities for a most intricate and close-grained diversity of uses . . . "74 Jacobs reasons that this high diversity of uses in an area results in dense social interaction. This density of social interaction then engenders anong the area's residents feelings of belonging and of responsibility for both the other residents and for strangers passing through. This attitude, in turn, is what makes these areas such emiching ones in which to live and in which to raise children.

Sennet argues that many of the contemporary social problems are accentuated by material abundance, particularly as represented in suburban living. 75 This material abundance relieves people from the necessity to interact and share with those around them in order to survive. This lack of interaction results in people holding a false sense of community with those around them, and clinging to rigid stereotypes concerning individuals who they perceive as different from themselves. Sennet concludes that the healthiest kind of environment would be dense city living in which there was a bare minimum of external controls so that individuals were forced to interact meaningfully with others who were different from themselves.

${ }^{74}$ Jane Jacobs, The Death and Life of Great American Cities, (New York: Randon House, Inc., 1961), p. 14.

75Richard Sennett, The Uses of Disorder, (New York: Random House, Inc., 1970). 
The choice which an individual makes between low-density living and accessibility to the CBD can also be studied in terms of the life style which the individual has opted for, and his location in the life cycle. Studies of urban living generally recognize three different life styles: consumerism, careerism, and familism. Any given individual's life style is a combination of aspects of these three basic life styles, but it is still possible for us to study each of the three types in isolation. Individuals who opt for the consumerism or careerism life styles tend to place a high value on accesibility to the $C B D$ since that is where the greatest opportunities for the pursuit of these life styles is located. The choice which couples who opt for familism make between low-density living and accesibility to the $\mathrm{CBD}$ is more complicated.

Couples who opt for the familism life style undergo changing demands for low-density housing depending on their position in the life cycle. Before the birth of children the housing demands of those couples opting for familism are langely indistinguishable from the demands of those opting for careerism or consumerism. With the birth of children the orientation of familism couples towards the CBD begins to be replaced by a concern with neighborhood quality and a desire for open space. The distance to locations such as schools and recreational areas becomes more important, and in the effort to minimize the total trip distances the family will often opt for a longer distance to work.

Once the children have grown up and left home the need for space generally declines, and the couple--particularly after retirement--often move into a house or apartment closer to the CBD. At this end of the life cycle their housing demands once again resemble those of individuals 
who opted for consumerism or careerism. Careerism's emphasis on occupational mobility may also cause people to live further out in nice residential areas if their occupation is one in which it is important to live in a good neighborhood. But the effects of this trend on the demand for low-density living are not as pronounced as the effects of the trend associated with the familism life style.

The life style explanation for low-density living can be integrated into the structural theory. As long as the poor do not consistently opt for life styles which place a higher valuation on low-density living than the life styles chosen by those of high status, the structural theory is not contradicted.

In the attempts to construct a more sophisticated historical/ structural theory of urban form a major unsettled question is the relative influences exerted by population density and obsolescent housing in the decentralization of high status residents. This question acquires a practical significance since central cities have encountered resistence to efforts to alleviate their fiscal problems my metropolitan consolidation or by dispersing their poor residents among their outlying suburbs, and have focussed their efforts on trying to attract high status residents back to live in the central areas.

Vast sums of money have been spent through urban renewal and other programs to replace selected areas of deteriorating housing with luxury apartments and to rehabilitate the downtown business area. To a certain extent the rehabilitation of the CBD is aimed at attracting shoppers who live in outlying areas, but it is also undoubtedly aimed at making a central location more habitable to high status residents. 
The fact that these monies are being spent on the assumption that the obsolescence of central city housing is a major cause of the decentralization of high status individuals makes it important to establish the role which obsolescent housing actually plays. If population density were to prove the overriding factor then efforts to attract high statius residents back into the central area would seem hopeless, since re-creating suburban densities in central city areas would require prohibitive sums of money. Additionally, if population density is a major factor. in the decentralization of high status individuals then we would expect that most of the high status individuals who wanted to live in these new luxury apartments would not be individuals who are moving back into the central city from suburban areas, but individuals who have always lived in the central city. 
CHAPTER IV

\section{METHODOLOGY}

\section{UNITS OF STUDY}

Our study is an empirical investigation of various issues which are involved in the attempt to combine the historical and structural perspectives on urban form. Our basic unit of study is the Standand Metropolitan Statistical Area (SMSA). By definition SMSA's are composed of central cities with a population of 50,000 or greater and their surrounding, functionally dependent counties. Since we are going to compare central cities with the surrounding area a preferable unit of study would be "urbanized areas." The boundaries of urbanized areas are not forced to coincide with county boundaries as in the case of SMSA's, but are instead constructed to include a central city of 50,000 or more inhabitants and a surrounding area which meets a population density criterion. Because of this difference in definition umbanized areas contain less of the rural and agricultural population which often shows up in the outskirts of SMSA's. Schnore used urbanized areas in the study we referred to earlier. We would use them also but the relevant data are more readily available for SMSA's.

We deleted from oun study SMSA's whose central city had a population of less than 100,000 in 1970. This was necessary in order to keep our study manageable in scope and it is justified because most of the urban problems which plague cities in this country are concentrated 
in the langer cities. We also deleted from oun study the New York City and Chicago Consolidated Areas. These two areas were dropped because the vast size of their populations and the great number of lesser cities located in thein surrounding areas make them atypical.

\section{VARIABLES}

Our measure of the decentralization of high status residents is actually a measure of the decentralization of the financially well-to-do. We computed from 1970 Census data the percentage of each SMSA's families and unrelated individuals earning more than $\$ 25,000$ who lived in the central city, or cities in the cases where the SMSA included two central cities of similar size. ${ }^{76}$ Studying the decentralization of the rich is not completely equivalent to studying the dencentralization of high status residents: income is only one aspect of socioeconomic status, and if we are going to use only one variable to study the ecological distribution of socioeconomic status, education is the most useful. ${ }^{77}$ Yet our use of an income interpretation of socioeconomic status is justified because the fiscal problems of our cities are not caused by the flight of those with high socioeconomic status, but in particular by the flight of those with sizable real property and disposable income.

Previous studies in this area have measured various aspects of socioeconomic status: Schnore used median family income, per cent com-

76U.S. Bureau of the Census, Census of Population: 1970, Vol. I, CHARACTERISTICS OF THE POPULATION, Table 89.

${ }^{77}$ Calvin Schmid, et. al., "The Ecology of the American City: Further Comparison and Validation of Generalizations," American Sociological Review, 23 (1958), p. 392. 
pleting high school, and per cent white collar; Guest used the median years of education for persons 25 years and over; and Haggenty used the per cent college educated, the per cent professionals, and the per cent white collar. Haggerty also included two measures of individuals at the lower end of the status hierarchy which do not concern us. It would be an aid to interpretation if everyone used the same measures, but both Schnore and Haggerty report that consistent results were obtained for each of their measures of high status.

We will include among our independent variables a measure of the number of decades since the central city attained a population of $50,000.78$ As we mentioned in our theoretical section this variables has been falling into disrepute. It has been used in the past as an indicator of certain--often largely unspecified--processes which were felt to inevitably occur in cities with the passage of time. Our justification for including city age is that we will also include a measure of housing obsolescence. Since the deterioration of central city housing over time was used by Schnore as a possible explanation for the effects of city age, including both of the variables will allow us to test Schnore's hypothesis.

As a measure of the intensity of competition for central city land we use persons per square mile in the central city. ${ }^{79}$ This variable enables us to test the hypothesis of the structural theory that the decentralization of the rich is a result of the rich sacrificing accessi-

78U.S. Bureau of the Census, Census of Population: 1970, Vol. I, CHARACTERISTICS OF THE POPULATION, Table 7.

79 U.S. Bureau of the Census, Statistical Abstract of the United States: 1973, (94th edition.), Washington, D.C., 1973, Table 23. 
bility to the $C B D$ in exchange for low density housing. It would be preferable to use a measure of the density gradient in each SMSA as Guest has done. After all, the structural theory does not argue that the rich decentralize just because there is intense competition for central city land, but because the competition for land further out is less intense. And yet knowledge of the density gradient is not essential since we are not trying to explain how far out individuals have moved from the $\mathrm{CBD}-$-as Guest was trying to do--but merely to explain their movement out beyond the political boundary of the city. Additionally, density gradient measurements are not available for all SMSA's and by using our slightly less exact measure we are able to study all of the cities we are interested in instead of only a sample as Guest was forced to use. Oun measure varies in its adequacy from city to city since cities vary in the amount of their land which is even potentially habitable. A more accurate measure would be the density of population per land which is zoned residential or is potentially useful for that purpose. However, such information would be very difficult to acquire and the inaccurarcy present in our measure must be assumed to be random error.

As a measure of the obsolescence of central city housing we have calculated for each SMSA the percentage of its central city housing which was 20 years old or older in $1970 .^{80}$ The use of such a measure was suggested but not actually tried by both Schnore and Guest. By

80 Deciding at what age housing becomes obsolete must be done somewhat arbitrarily. After 10 years, the age of housing is listed only in 10 year categories. We chose 20 years over 30 years since 30 years seems overly conservative. U.S. Bureau of the Census, Census of Population and Housing: 1970, CENSUS TRACTS, Final Report PCH(1), Table H-2. 
including this measure we will be able to explicitly test various hypotheses put forward by Schnore and Guest concerning the relationship between city age and obsolescent housing and the role of obsolescent housing in the historical/structural model.

The independent variables we have listed so far are the ones whose influence over the decentralization of the well-to-do is of interest to us. In addition to these variables there are other sources of systematic variation across SMSA's in the decentralization of the well-to-do which are of no theoretical interest to us but which we will want to control for. We will control for two such sources of variation. First, we will control for the per cent of the SMSA population which is located within the central city. ${ }^{81}$ This is necessary because lange cities no longer contain within their political boundaries all of the land whose use is determined by its proximity to the central city, and whose residents are dependent on the city for services or even for their very jobs. In the SMSA's in our study the per cent of the SMSA population which is located in the central city varies from the high 90's to under 20. We have to control for this variation since unless the well-to-do have less of a tendency to live on the outskirts of cities than other groups, we would find that the greater the percentage of the SMSA population contained in the suburban ring the greater is the decentralization of the well-to-do.

Second, we will control for the per cent of the SMSA employment which is located in the central city. ${ }^{82}$ In our study this varies from the high $90^{\prime}$ 's to under 30 . The presence of jobs outside of the central

$$
{ }^{81} \text { Ibid.; Table P-1. }{ }^{82} \text { Ibid., Table P-2. }
$$


city is an influence on residential location which is worthy of investigation in its own right. Yet it just serves to obscure the theoretical issue we are interested in. In particular it invalidates the assumption of the structural theory that it is the cost of commuting from a suburban residence to a central city job which prevents the poorer members of society from living outside of the central city. After all, it is the industries which require minimal skills which tend to suburbanize fastest, and it is the low-skill workers who have the strongest desire to reside close to their place of work since transportation costs form a larger share of their budget.

\section{MODELS USED IN THE ANALYSIS}

In our study we will present three models of the decentralization of the well-to-do. These models are designed to illustrate various issues involved in the attempt to integrate the historical and structural theories.

Model 1

Our first model will serve as a demonstration of the importance of controlling for the effect which the decentralization of employment and population exerts on the decentralization of the well-to-do.

Model 1 can be represented by the following equation:

$$
\begin{aligned}
\mathrm{X}_{0}=\mathrm{BX}_{1} & +\mathrm{BX}_{2}+\mathrm{BX}_{3}+\mathrm{BX}_{4} \\
\text { Where } \mathrm{X}_{0} & =\text { decentralization of the well-to-do } \\
\mathrm{X}_{1} & =\text { decentralization of employment } \\
\mathrm{X}_{2} & =\text { decentralization of population }
\end{aligned}
$$


$x_{3}=$ city age

$\mathrm{X}_{4}=$ population density

The $B^{\prime} s$ in this equation are the standardized partial regression coefficients or "path" coefficients and they tell us the effect which each independent variable exerts on the dependent variable when the effects of the other independent variables are controlled for. We expect that our four independent variables will be highly intercorrelated, but this does not concern us at this point since we are interested in the theoretical implications of the unique effects of the variables and we assume that the intercorrelations among then are not causal in nature but instead derive from the dependence of the independent variables on antecedant causes which are not included in the model.

Model 1 represents the basic attempt to depict Alonso's contrast between the historical and structural perspectives. Schnore suggested that city age affects the decentralization of the well-to-do by virtue of city age's effect on both housing obsolescence and intensity of competition for central city land. Since this model includes population density as an indicator of competition for central city land, we expect the independent effect of city age to represent the effect of housing obsolescence. Indeed, Haggerty's investigation of the historical and structural theories used city age for that very purpose.

Model 2

In our second model the effects of the decentralization of population and employment will be controlled by simply regressing our dependent variable on the two control variables, using the resulting regression 
equation to predict the values of the dependent variables, and then using the resulting residuals as the new dependent variable. This procedure removes the variability in decentralization of the well-to-do which is attributable to population decentralization and employment decentralization. We will then regress this variable on city age and population density.

The correlation between our exogenous variables will no longer be taken as a given: we will follow Schnore's hypothesis and depict city age as a cause of population density. This model allows us an uncluttered view of the relationship between population density and city age and also allows us to examine the independent effect which each exerts on the decentralization of the well-to-do. In addition, it prepares us to study the changes which occur in these effects when we introduce housing obsolescence into the model.

Model 2 can be represented by the following equation:

$\mathrm{X}_{0 / 12}=\mathrm{BX}_{3}+\mathrm{BX}_{4}$

Where $x_{0}=$ decentralization of the well-to-do

$X_{1}=$ decentralization of employment

$x_{2}=$ decentralization of population

$\mathrm{x}_{3}=$ city age

$x_{4}=$ population density

Model 3

Our thind model is simply the second model with the addition of housing obsolescence. This model allows us to investigate more completely Schnore's hypothesis that city age's influence over decentrali- 
zation of high status residents results from city age's influence on housing obsolescence and intensity of competition for central city land. This model will also allow us to investigate Guest's hypothesis of the role of housing obsolescence in the historical/stmuctural model.

Model 3 can be represented by the following equation:

$\mathrm{X}_{0} / 12=\mathrm{BX}_{3}+B \mathrm{BX}_{4}+\mathrm{BX}_{5}$

Where $\mathrm{X}_{0}=$ decentralization of the well-to-do

$x_{1}=$ decentralization of employment

$\mathrm{x}_{2}=$ decentralization of population

$\mathrm{x}_{3}=$ city age

$\mathrm{x}_{4}=$ population density

$\mathrm{x}_{5}=$ housing obsolescence

Where appropriate, the signs of the path coefficients will be reversed. This is necessary because the models are in terms of decentralization, while several of the variables are calculated as indices. of centralization. 


\section{CHAPTER V}

\section{ANALYYSIS OF DATA}

The results shown in Figure 1 support our decision to control

for the effects of population decentralization and employment decentralization. Either of them exert a stronger independent effect than population density or city age exert. The importance of controlling for the decentralization of population and employment is further underlined by the fact that this model explains 80 percent of the variation in our dependent variable.

Of the two variables of theoretical interest to us, population density exerts the greater independent effect. When the effects of the other three independent variables are controlled for, the path coefficient from population density to decentralization of the well-to-do is equal to .26 . In contrast, the path coefficient from city age to decentralization of the well-to-do is only .08 when the effects of the other three independent variables are controlled for. The greater independent effect of population density also shows up in Figure 2. After eliminating the variability in decentralization of the well-to-do which is attributable to population decentralization and employment decentralization, the path coefficient from population density is equal to .32 , while that from city age is equal to .16 .

The drop in the zero onder correlation of .37 (Figure 4) between city age and decentralization of the well-to-do to a path coefficient 


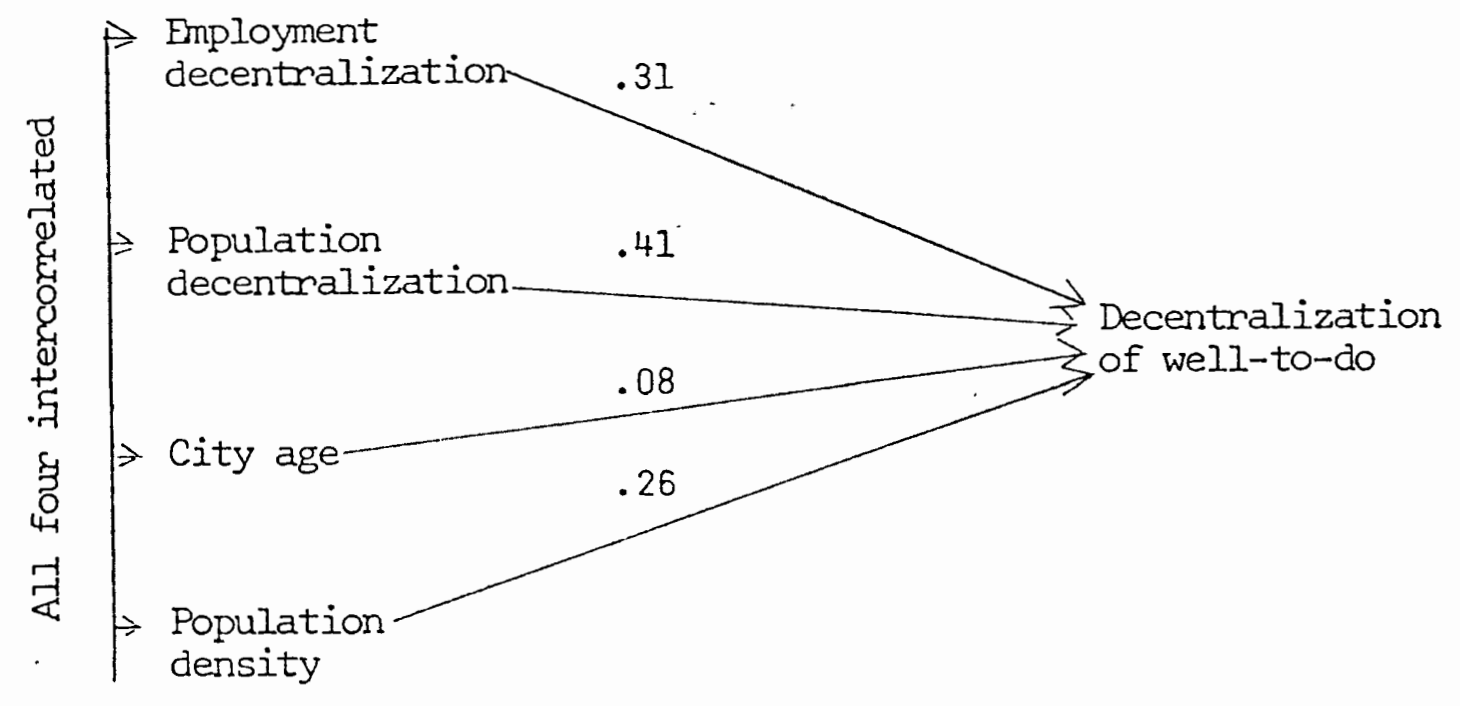

Figure 1. Path diagram of Model 1. $\mathrm{n}=112 \quad \mathrm{R}^{2}=.80$ 


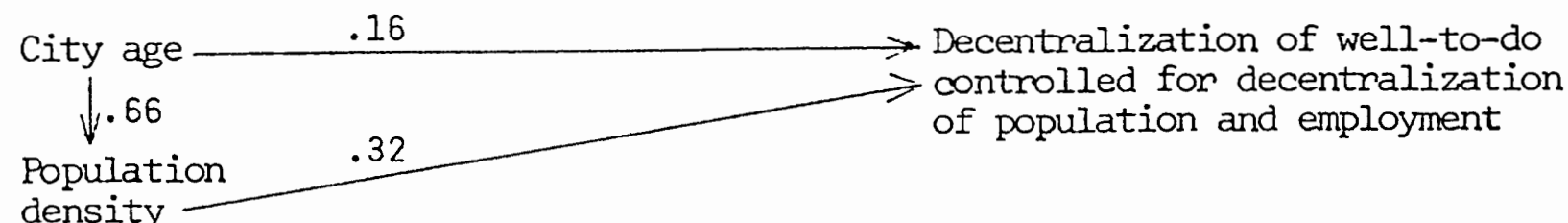

Figure 2. Path diagram of Model $2 \quad n=112 \quad R^{2}=.18$ 
of .16 wher population density is controlled for, supports Schnore's hypothesis that the effect of city age on decentralization of the wellto-do is partially due to city age's effect on intensity of competition for central city land. Schnore hypothesized that city age effects decentralization of the well-to-do by virtue of city age's effect on housing obsolescence and the intensity of competition for central city land. If we accept that population density is an approximate measure of intensity of competition for central city land then Figure 2 becomes a simple comparison of the historical and structural theories as they are formulated by Alonso.

In so far as the conflict between the historical and structural theories is adequately represented by this model, we would be inclined to dismiss the historical theory in favor of the structural. This is the conclusion which Haggerty reached when he compared the effects which population density and city age exerted on the change between 1950 and 1960 in the distribution of high status residents within 28 cities studied on a tract-by-tract basis. ${ }^{83}$ Haggerty's study was even more hostile than ours to the historical theory as formulated by Alonso, since Haggerty found a negative relationship to exist between city age and decentralization of high status residents when the effects of other variables were controlled for.

Our analysis to this point has used city age as an indirect measure of housing obsolescence. In Figure 3 we include an actual measure of housing obsolescence which allows us to examine more pre-

${ }^{83}$ Haggerty, p. 12. 


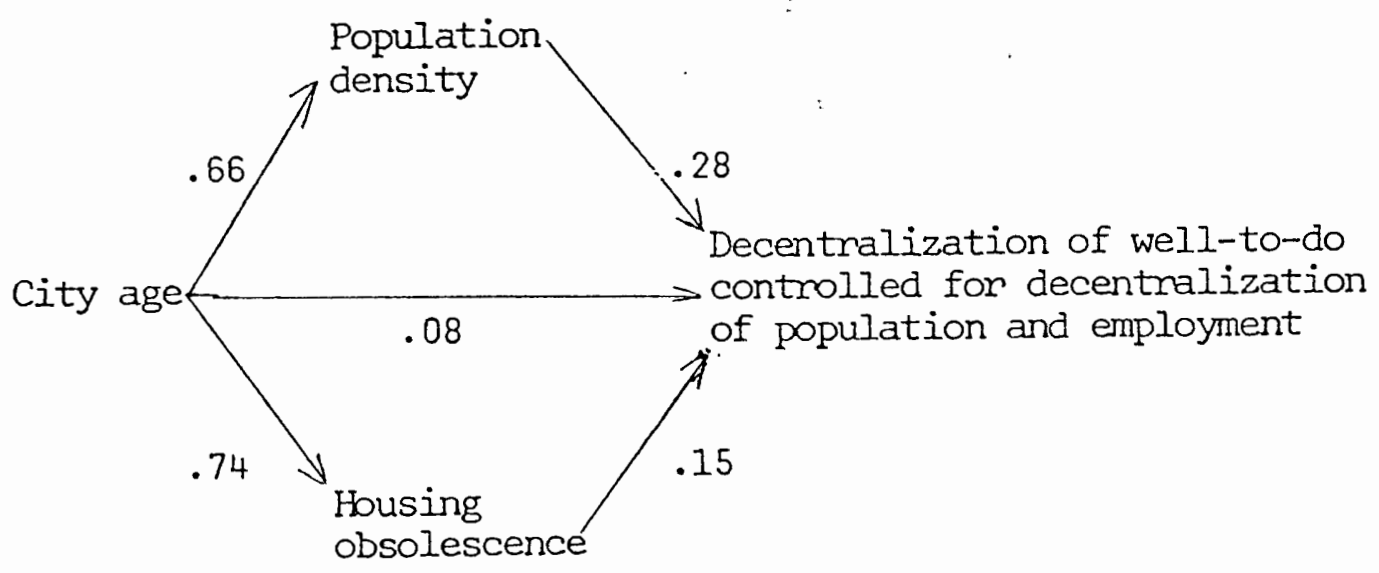

Figure 3. Path diagram of Model 3. $n=112 \quad R^{2}=.21$ 
cisely the issues we are interested in. The addition of housing obsolescence further reduces the independent effect of city age on decentralization of the well-to-do from .16 to .08. This is a very slight relationship, though we have still failed to support Haggerty's finding of a negative relationship between the two. Hence we can support Schnore's hypothesis that city age's influence over the decentralization of high status individuals is langely explained by city age's influence on population density and housing obsolescence.

The use of an actual measure of housing obsolescence in Figure 3 allows us to repeat more strongly our earlier conclusion that density exerts a greater independent effect over the decentralization of the well-to-do than does housing obsolescence. Yet the results also support Guest's suggestion that we need to incorporate housing obsolescence into the historical/structural model. While the $R^{2}$ of . 21 may seem unimpressive it is not out of step with the results of other studies in the area.

It is true that comparing our results with the results obtained in other studies is made more difficult by the lack of common measures for both the dependent and independent variables. But it is also true that if people reach similar conclusions despite the use of variables which measure slightly different aspects of the same phenomena, our confidence in those conclusions and our understanding of their true significance is enhanced over what it would be if all the studies made use of exactly the same variables and statistical techniques. 
TABLE I

ZERO-ORDER CORRELATIONS AMONG THE VARIABLES IN FIGURE 3

$\begin{array}{lll}\text { Decentralization } & \begin{array}{l}\text { Population City age Housing } \\
\text { of well-to-do }\end{array} & \text { density }\end{array} \quad$\begin{tabular}{l} 
obsolescence \\
\hline
\end{tabular}

Decentralization

of well-to-do

1.00

Population

density

$.43 \quad \cdots \quad 1.00$

City age

.37

.66

1.00

Housing

obsolescence

.39

.65

.74

1.00 
CHAPTER VI

CONCIUSIONS

Our findings show that it is a mistake to reject the inclusion of historical factors in an overall theory of urban form simply because of the inadequacy of city age as a variable. Our demonstration of the independent effects of housing obsolescence on the decentralization of the well-to-do supports Guest's hypothesis that the amount of growth which a city experienced during different eras affects the present location of high status residents because of the effect of the population growth on both the density gradient, and the current patterns of housing obsolescence.

The main gap remaining in the theory as formulated by Schnore and Guest is the effect which changing patterns of non-residential land use exert on the decentralization of high status residents. This question is much harder to study than the question of the effects of housing age. We lack a theory setting out in clearly testable form what aspects of non-residential land use are important. To a certain extent the historical/structural theory controls for the location of non-residential land uses through its examination of the intensity of competition for central city land. This approach controls for that influence of non-residential land use which results from the feedback relationship between the location of non-residential land uses and the cost of urban land: the location of non-residential land uses is 
determined in part by variation in land costs in the urban area and also helps determine this variation, while at the same time the historical/structural theory suggests that the outcome of the trade-off which high status residents make between accessibility and low density living

is dependent on the spatial patterning of land costs. This effect is what Guest is trying to measure through his use of the density gradient, since Guest perceives the density gradient as an approximate measure of the differences in land use intensity and hence land costs.

Yet the effects of non-residential land uses on the location of high status residents are not limited to their effect on land costs: the location of certain non-residential land uses can exert either an attraction or repulsion for certain social classes. Harris and Ullman, for example, in their description of urban areas noted that the location of noxious industries will repel high status residential areas. ${ }^{84}$ But these sorts of tentative statements are not sufficient to enable us to incorporate the effects of changing patterns of non-residential land use directly into our model.

The changing distribution of different types of non-residential land use which have resulted from the changes in transportation technology can not be handled satisfactorily until we have systematic theoretical statements of the effects which the distribution of different types of non-residential land uses of different ages exert on the location of various social classes. We can not simply assume that the various classspecific effects exerted by non-residential land uses will cancel each other out. For example, the noxious industries which repel high status

${ }^{84} \mathrm{C}$. D. Harris and E. L. Ullman, "The Nature of Cities," Annals of the American Academy of Political and Social Science, 242 (1945), pp. 7-17. 
residential areas frequently employ low-skill workers and hence tend to attract low status residential areas. Therefore, we would expect a concentration of noxious industries in a central city to result in a greater decentralization of high status residents than would a comparable concentration of some other kind of non-residential land use.

In the absence of theoretical predictions about the effects of specific non-residential land uses it seems that the best approach is to try and control for the distribution of non-residential land uses in a more basic way than Guest has done. This is what we have attempted to do by controlling for the distribution of employment within the urban area. By controlling for the distribution of non-residential land uses in this way we are assuming that the most important class-specific effects exerted by the location of non-residential land uses are those effects exented by the location of employing concerns, and, further, that those employing concerns which exert important class-specific effects (such as noxious industries, or particularly old dilapidated industries, etc.) tend to be distributed in similar patterns in diffexent urban areas. Even though this position is langely an assumption it seems preferable to simply ignoring altogether these effects of non-residential land uses as Guest has done.

The next step for research is to select variables and procedures which more faithfully reflect the theoretical issues we are interested in. Additionally, we will want to integrate our housing obsolescence measure into Guest's model since his model is the most direct attempt to operationalize the issues involved. A new study should be based on a sample of SMSA's so that we can compute the change with occurred 
with increasing distance from the CED in the income of tract residents. Similar tract-by-tract study of a sanple of cities appears in the work of both Guest and Haggerty and seems the appropriate mode of analysis since it allows us to examine the actual distribution of a social group instead of just the extent to which the group is over-represented in outlying areas.

In a new study we would supplement our analysis of the distribution of the well-to-do with an analysis of the distribution of the well educated since education is the most effective indicator of the ecological distribution of socioeconomic status. By studying both the well-to-do and the highly educated we can examine a discrepancy which has existed in similar studies between the theoretical rationale of the model and the way the model has been operationalized. The basic historical/structural model assumes that there is no variation across social classes in the way individuals value low density living. The model then reasons that individuals decentralize as a function of their ability to afford the added conmuting costs involved in suburban living. Yet the model has been tested almost solely in terms of its ability to explain the location of socioeconomic groups. The only dependent variable Guest uses is a measure of the median educational attainment of tract residents; Haggerty uses three different measures of the distribution of high status residents and yet not one of them measures the distribution of the wealthy. It is understandable that sociologists want to study the distribution of socioeconomic groups within urban areas since such groups are a more sociologically meaningful construct than a group defined solely in terms of its income. However, we would 
suggest that the tendency of past rescanchers to test the historical/ structural model by its explanation of the distribution of individuals of high status is a misinterpretation of the model since the model does not claim that individuals with high social status will tend to decentralize but that wealthy individuals will tend to decentralize. The tendency of individuals with high social status to decentralize is not directly implied by the model but derives from the correlation between an individual's wealth and his socioeconomic status.

We would suggest that the extent to which the model explains the distribution of persons with high socioeconomic status is a secondary issue compared to the extent to which it explains the distribution of the wealthy. Moreover, in re-testing the model to incorporate dependent variables measuring the distributions of both the wealthy and the highly educated we would be testing the hypothesis that the model more accurately explains the distribution of the wealthy than the distribution of the highly educated. For if the model were more effective at explaining the distribution of the highly educated than at explaining the distribution of the wealthy this would at least call into question the rationalization of the decentralization of high status persons solely in terms of their greater ability to afford the costs involved in commuting and suggest the possibility that there are significant social class differences in the valuation of low density living and/or modem housing.

We would include in our new model measures of the current gradients in population density and in housing obsolescence. We would also include measures of the amount of growth which the city experienced in each of the three main transportation eras. We would control our de- 
pendent variables for the decentralization of crp?oyment within the SMSA and would then test the model with each of our dependent variables to see which of the two of them it more adequately described, and to see the extent to which the effect of earlier population growth is explained by its effect on current gradients in population density and housing obsolescence. This model will be an improvement over Guest's both because of its explicit inclusion of housing obsolescence and because of its more appropriate control over the effects of the location of non-residential land uses. 


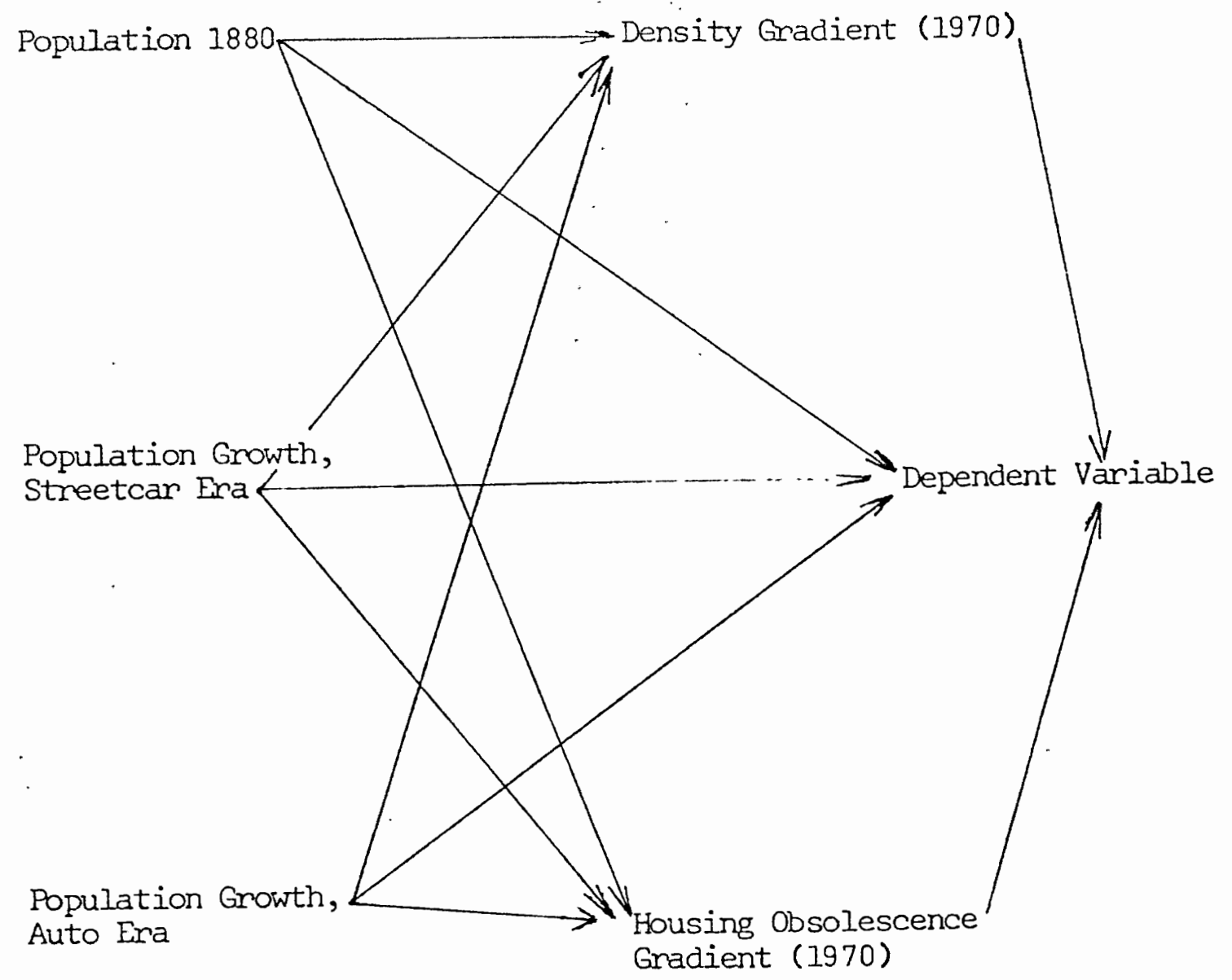

Figure 4. Expanded historical/stmuctural model 


\section{BIBLIOGRAPHY}

Alonso, William, "The Historic and the Structural Theories of Urban Form: Their Implications for Urban Renewal," Iand Economics, XL (1964).

Bimbaum, Max, and Mogey, John, ed., Social Change in Unban America, (New York: Harper \& Row, Publishers, 1972).

Bungess, Ernest, "The Growth of the City: An Introduction to a Research Project," The City, ed. Robert Park, Ernest Burgess, and R. D. McKenzie, (Chicago: University of Chicago Press, 1925).

Cox, Kevin, Conflict, Power and Politics in the City, (New York: McGraw-Hill Book Company, 1973).

Downs, Anthony, Opening Up the Suburbs, (New Haven: Yale University Press, 1973).

Downs, Bryan ed., Cities and Suburbs, (Belmont, California: Wadsworth Publishing Company, 1971).

Engelbert, Emest ed., The Nature and Control of Urban Dispersion, (Berkeley: The University of California Printing Department, 1960).

Firey, Walter, "Sentiment and Symbolism as Ecological Variables," Studies in Human Ecology, ed. George Theodorson, (Evanston: Row, Peterson and Company, 1961).

Fried, Marc, "Grieving for a Lost Home: Psychological Costs of Relocation," Urban Renewal, ed. James Wilson (Cambridge: The M.I.T. Press, 1967.

Guest, Avery, "Urban History, Population Densities, and Higher Status Residential Location," Economic Geography 48 (1972).

Haggerty, Lee, "An Empirical Assessment of Urban Renewal Theory: Density vs. Age of City," unpublished manuscript, Department of Sociology, Portland State University.

Harmis, C. D., and Ullman, "The Nature of Cities," Annals of the American Academy of Political and Social Science, 242 (1945).

Hoyt, Homer, The Structume and Growth of Residential Neighborhoods in American Cities, (Washington, D. C.: Federal Housing Administration, 1939). 
Jacobs, Jane, The Death and Life of Great American Cities,' (New York: Random House, Inc., 1961).

Johnston, R. J., Urban Residential Patterns, (Iondon: G. Bell and Sons, Ltd. , 1971).

Kramer, John ed., North American Suburbs, (Berkeley: The Glendessary Press, 1972).

Lineberry, Robert, and Sharkansky, Ira, Urban Politics and Public Policy, (New York: Harper \& Row, Publishers, 1971).

Masotti, Louis, and Hadden, Jeffrey, Suburbia in Transition, (New York: New Viewpoints, 1974).

Schnid, Calvin, "The Ecology of the American City: Further Comparison and Validation of Generalizations," American Sociological Review, 23 (1958).

Schnore, Leo, The Urban Scene, (New York: The Free Press, 1965).

Sennett, Richard, The Uses of Disorder, (New York: Random House, Inc. 1970).

Wirth, Louis, "Urbanism as a Way of Life," The American Journal of Sociology, 44 (1938). 